
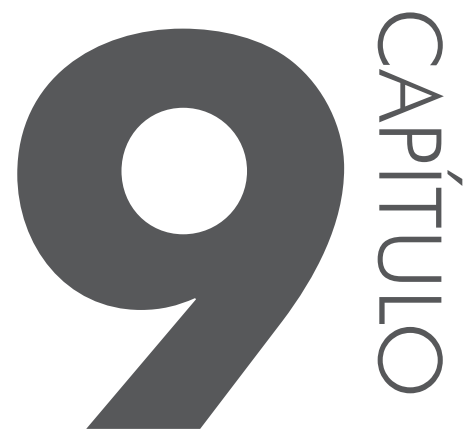

\title{
Missão Kadila: percepções sobre Luanda, vale do Kuroka e Parque Nacional do Yona
}

\author{
Nazareno José de Campos \\ Universidade Federal de Santa Catarina
}

\section{Introdução}

O presente capítulo é resultado de atividades que foram desenvolvidas em Angola no período entre 31 de maio e 29 de junho de 2015, sendo uma parte em Luanda e um tempo maior de trabalho dedicado à região desértica do sudoeste do país, província de Namibe (Figura 9.1). Mais especificamente, as atividades ocorreram em espaços geográficos e socioculturais dominados por populações de pastores transumantes do vale do Kuroka e do Parque Nacional do Yona, em cujos ambientes geográficos nem sempre se tem acesso fácil, dadas as longas distâncias, dificuldades infraestruturais, constantes deslocamentos e logística em geral. Tratou-se de uma missão de trabalho que integra o projeto Kadila, desenvolvido pelo Núcleo de Estudos sobre Identidade e Relações Interétnicas - NUER/ UFSC - e financiado pelo Programa Mobilidade Internacional da Capes. ${ }^{9}$

9 Especificamente à missão em Angola, saliento a ajuda do programa Capes/AULP (Processo BEX 3118/15-0), bem como a concessão de estadia em Luanda pela Faculdade de Letras da UAN. 


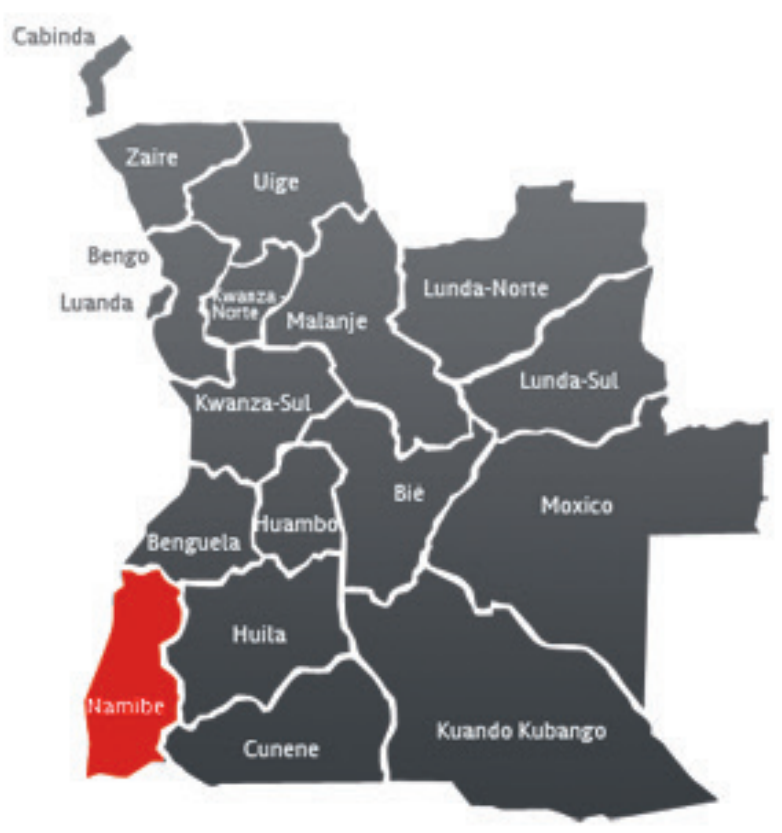

Figura 9.1 - Localização da província do Namibe em território angolano. Fonte: <http://www.portalangop.co.ao/ angola/pt_pt/portal/provincias/namibe/>.

Em 1 de junho de 2015, tiveram início os trabalhos de preparação para as atividades que seriam desenvolvidas no deserto, cujo ponto de partida foi uma reunião administrativa, ocorrida na Faculdade de Letras da Universidade Agostinho Neto - UAN, com parte de seu corpo docente, coordenada pela professora e decana da faculdade, Amélia Arlete Rodrigues Mingas. Essa reunião definiu alguns direcionamentos, cristalizando a Faculdade de Letras como o órgão da UAN mais diretamente inserido no convênio UFSC-UAN em relação ao projeto Kadila. ${ }^{10}$ Após a reunião, antes mesmo que se concretizasse a viagem ao Namibe,

10 Além da professora Arlete Mingas, estiveram também presentes: o vice-decano da faculdade, Nginamau Petelo (da área de literatura); Daniel Peres Sassuco (chefe do Departamento de Línguas e Literatura Africana); Narciso Benedito Homem, docente do Departamento de Línguas Africanas; Cesar Faria da Silva, do Departamento de Filosofia e com domínio na área de antropologia filosófica; Domingas Henriques Monteiro, do Departamento de Línguas e Literatura Africana e com domínio em literatura oral e línguas kikongo, kibundo, zaire e lunda; Jordão Caculo, chefe do Departamento de Documentação e Informação Cientifica; Simão Kikamba, chefe do Departamento de Línguas e Literatura Inglesa; Alexandre Chicuna, chefe do Departamento de Investigação Cientifica. Deste grupo, acompanhou-nos ao deserto do Namibe, no sul do país, a professora Arlete Mingas e o professor Narciso Homem, ambos da área de linguística. 
realizei uma série de atividades na capital, Luanda, para a obtenção de material bibliográfico, documental e cartográfico que proporcionasse alguns elementos prévios de conhecimento das áreas desérticas do sul e das populações que lá vivem, agilizando assim o trabalho naquela região. Não obstante, as atividades, conjugadas a observações empíricas, me fizeram perceber que aquela cidade-capital possui especificidades não encontradas na maior parte do país, perfazendo hoje um município totalmente urbano, que em sua área metropolitana possui uma população que ultrapassa os seis milhões de habitantes. ${ }^{11}$ Enfim, as observações e análises referentes a dois espaços geográficos tão diferentes (uma região metropolitana de forte concentração urbana em relação a espaços da região desértica de reduzida demografia) serviram como um ótimo parâmetro comparativo entre realidades tão diversas.

\section{Luanda na afualidade: aspectos de sua economia e sociedade}

Terminada a guerra civil em Angola no alvorecer do século XXI, e considerando a própria dinâmica da economia mundial, o país passa por um rápido crescimento econômico, corroborado pela presença de muitos capitais estrangeiros (chineses, brasileiros, europeus, norte-americanos, entre outros) e, igualmente, pela presença de empresas nacionais, denotando uma dinâmica capitalista bastante atuante, sob o beneplácito do Estado. ${ }^{12}$ Em tal processo, é marcante o dinamismo urbano, gerando um frenético movimento de construção civil, caracterizado por marcante verticalização (Figuras 9.2 e 9.3), produzida por diferentes incorporadoras nacionais e estrangeiras.

11 Segundo dados do INE - Instituto Nacional de Estatística - Resultados Preliminares do Censo de 2014, a população do município de Luanda é de 2.107.648 habitantes, enquanto a província de Luanda, que comporta respectivamente a área metropolitana da capital (sete municípios que integram a província de Luanda), possui um total de 6.542.944 habitantes. Destes, apenas 165.698 habitantes são identificados como rurais.

$12 \mathrm{O}$ Estado está bem presente na atual economia angolana. Percebemos isto já no inicio de nossa estadia em Luanda. Os noticiários televisivos e a imprensa escrita não cansavam de noticiar a viagem internacional que o presidente José Eduardo dos Santos, acompanhado de uma comitiva de ministros e assessores, realizava naquele período pela China, Europa e Oriente Médio, com o intuito de firmar negócios, em especial na área econômica. Seu domínio é atuante em setores como educação, saúde, assistência social e inclusive a mídia, cujo canal estatal de televisão tem grande influência, como, por exemplo, por meio de sua programação jornalística diária. 


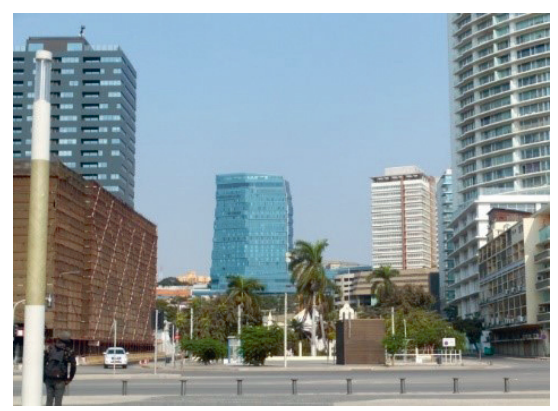

Figura 9.2 - Luanda atual: muitos prédios novos. Fonte: foto de Nazareno Campos.

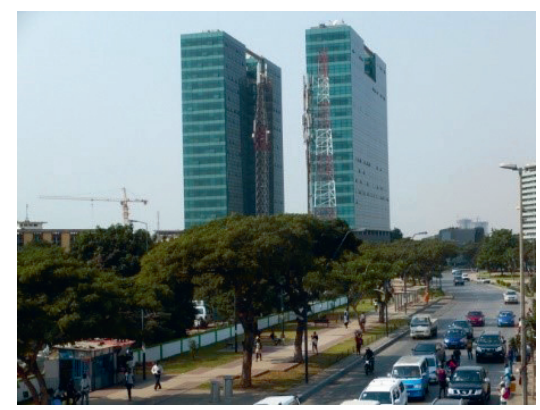

Figura 9.3 - Luanda atual: muitos prédios em construção. Fonte: foto de Nazareno Campos.

Esse movimento de urbanização e modernidade tem avançado sobre construções de arquitetura tradicional, muitas delas se encontrando deterioradas e com possibilidades de especulação imobiliária (Figuras 9.4 e 9.5).

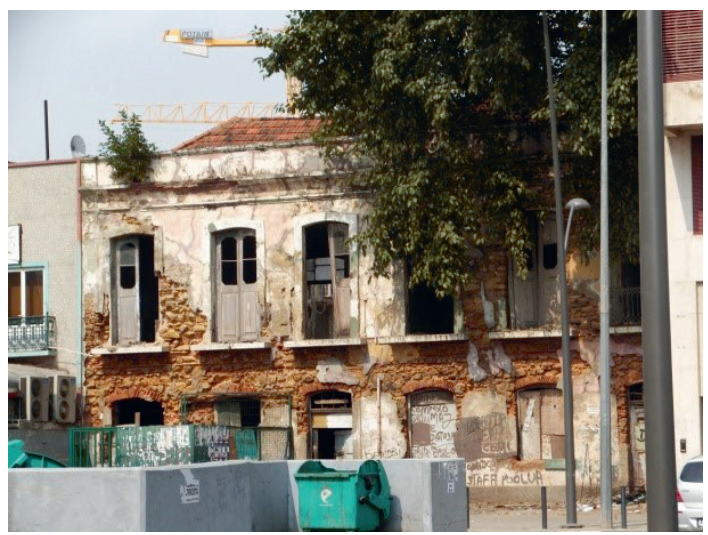

Figura 9.4 - 0 patrimônio arquitetônico de valor histórico. Fonte: foto de Nazareno Campos. 


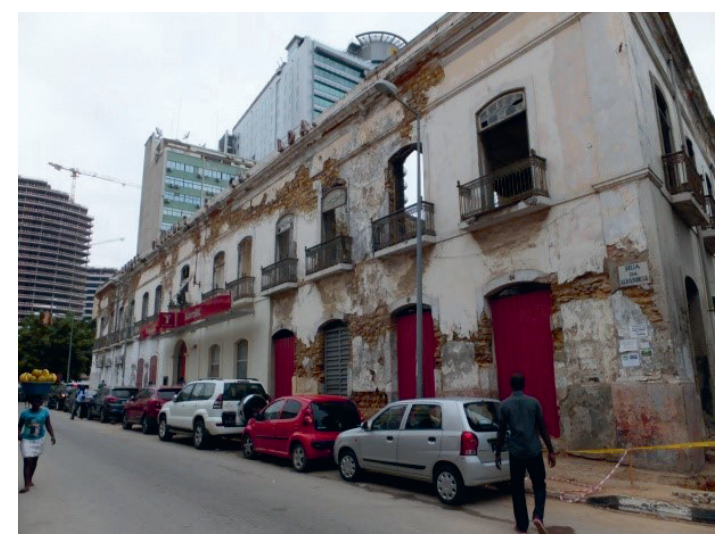

Figura 9.5 - 0 patrimônio arquitetônico de valor histórico. Fonte: foto de Nazareno Campos.

Toda essa transformação demográfica e urbana de Luanda é muito recente, e seu crescimento se deu com extrema rapidez, principalmente em decorrência de imensa migração do interior do país para a capital, tendo em conta, principalmente, os difíceis anos de guerra civil.

Entretanto, os problemas sociais já são percebidos nas primeiras décadas do século XX, conforme fica implícito no comentário de Nuno Simões ao retratar a ação do poder público quanto ao "problema da habitação, do vestuário e da alimentação indígena", além do alcoolismo, publicado no Boletim da Agência Geral das Colônias, de 1929. Problemas sociais esses bastante acentuados nos dias de hoje, percebidos nos bairros pobres com nítido aspecto de favelamento, nas carências infraestruturais urbanas, no desemprego, entre outros. ${ }^{13}$ Há, portanto, um pronunciado processo de modernização da cidade, percebido nas modernas avenidas, aterros, estruturas urbanas e prédios institucionais (Figuras 9.6 a 9.9). Em grande medida, as construções demonstram um alto padrão arquitetônico, o que certamente evidencia um espaço valorizado, com elevado preço do solo urbano, não compatível com os interesses e possibilidades da população em geral. Muitos prédios de companhias estatais e mesmo privados demonstram ostentação (Figuras 9.10 e 9.11), o que é igualmente percebido nos veículos que circulam nas vias urbanas e rodovias (muitas caminhonetes e automóveis de alto padrão), em grande parte importados do Catar e Emirados Árabes.

13 A própria demografia evidencia as fortes transformações ao conferir para Luanda 480.613 habitantes em 1972, enquanto a população do país, em estimativa de 1975 , girava em torno de 6.761.000, ou seja, basicamente a população que hoje possui apenas a área metropolitana da capital (GEO, volume 5 - África, 1977, p. 1660). 


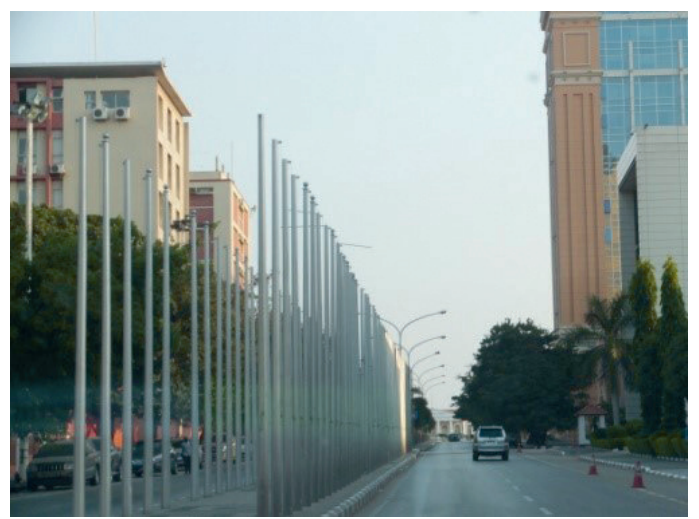

Figura 9.6 - Moderna avenida. Fonte: foto de Nazareno Campos.

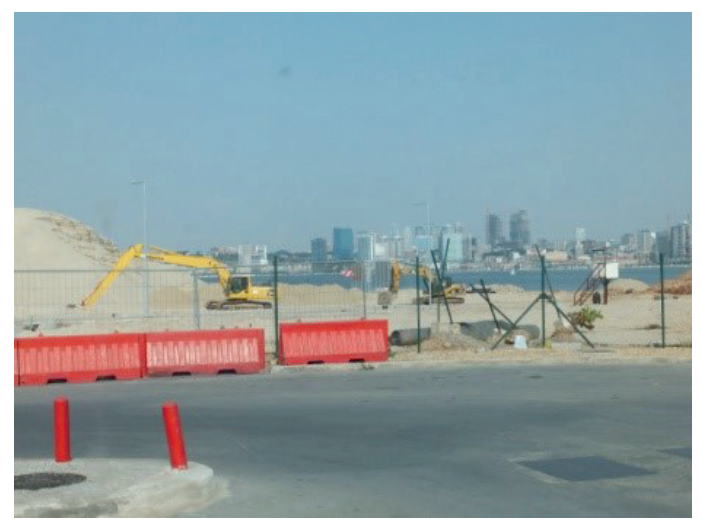

Figura 9.7 - Aterro. Fonte: foto de Nazareno Campos.

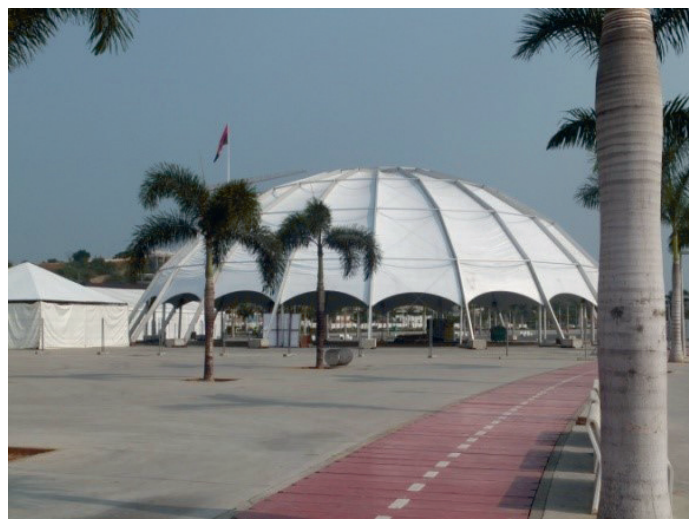

Figura 9.8 - Estrutura urbana de lazer. Fonte: foto de Nazareno Campos. 


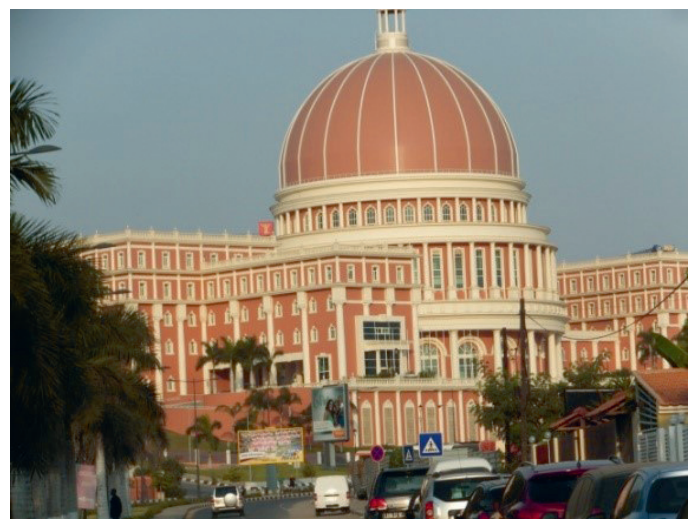

Figura 9.9 - Prédio institucional. Fonte: foto de Nazareno Campos.

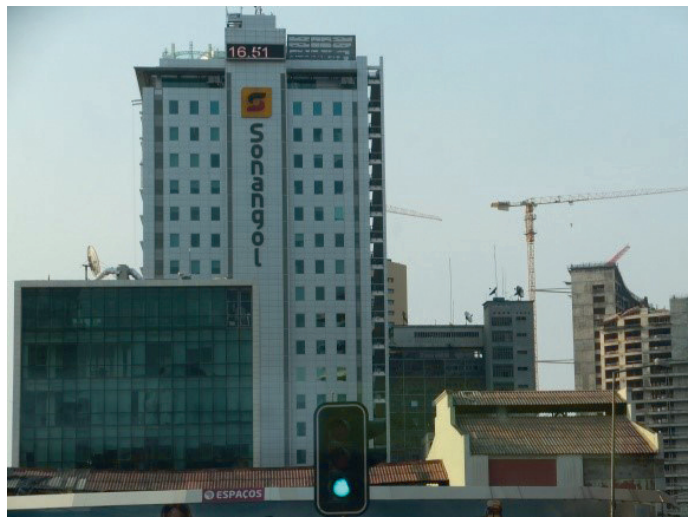

Figura 9.10 - Companhia estatal. Fonte: foto de Nazareno Campos.

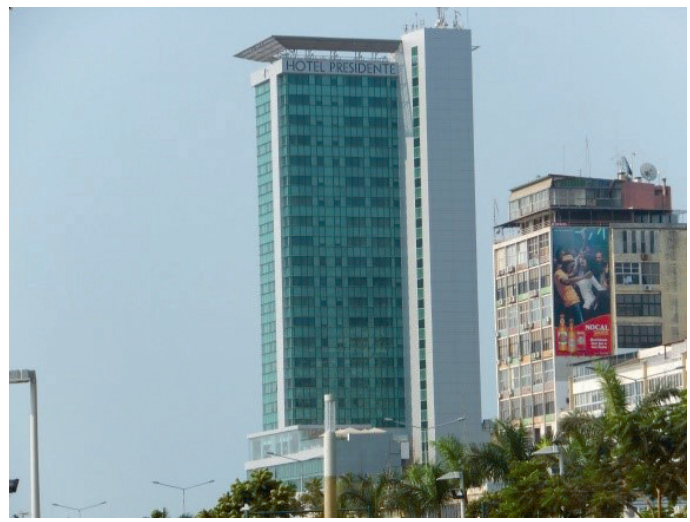

Figura 9.11 - Hotel classe A. Fonte: foto de Nazareno Campos. 
Percebe-se, assim, a formação de uma parte bem elitizada da população em contraste com grande parte que se mantém pobre, trabalhadora, vivendo em bairros empobrecidos ou em edifícios degradados (Figura 9.12), conjugado a situações de muito trabalho informal, trânsito complicado e dificuldade de acessibilidade e movimento das pessoas em vários pontos do meio urbano (Figura 9.13). Portanto, as infraestruturas urbanas não acompanham o rápido crescimento, a exemplo das ruas com péssimo estado de conservação, sem calçadas ou com calçadas irregulares, sem saneamento em muitas partes, cujo esgoto corre a céu aberto e onde se vê a presença de muito lixo espalhado (Figura 9.14), de modo que as pessoas e os carros se misturam nas vias.

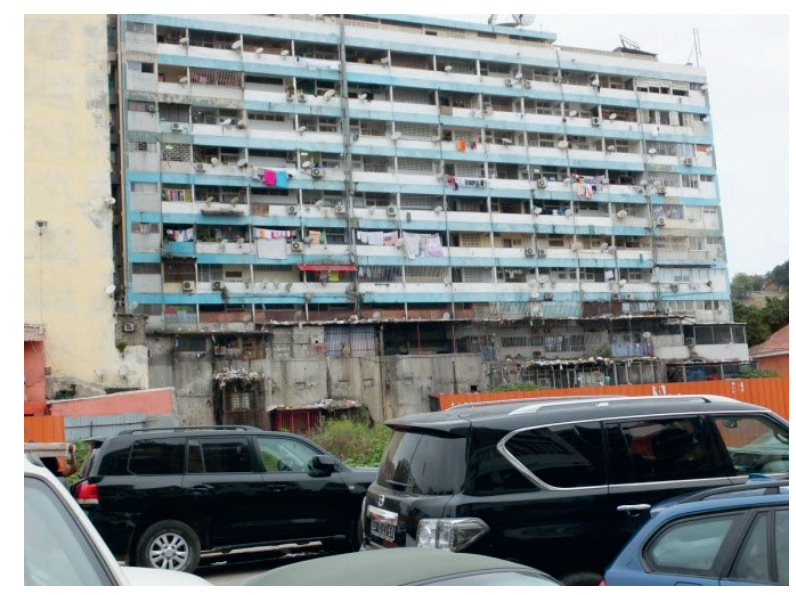

Figura 9.12 - Exemplo de edifício degradado. Fonte: foto de Nazareno Campos.

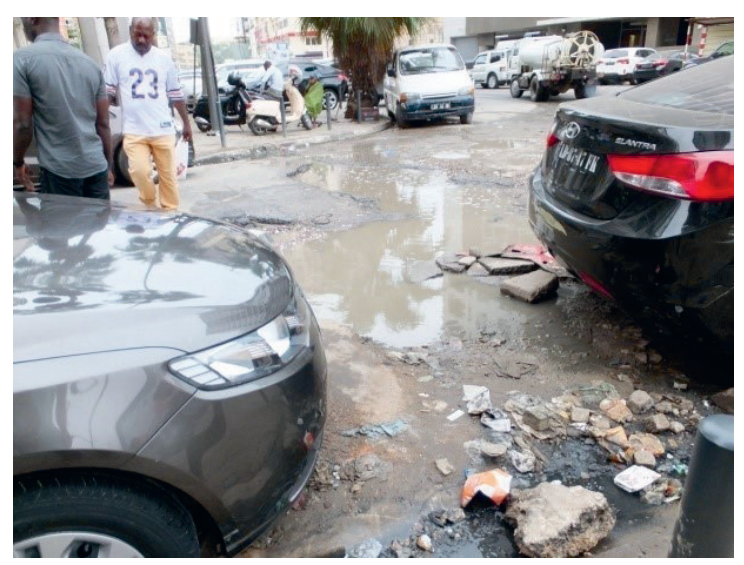

Figura 9.13 - Dificuldade de acessibilidade. Fonte: foto de Nazareno Campos. 


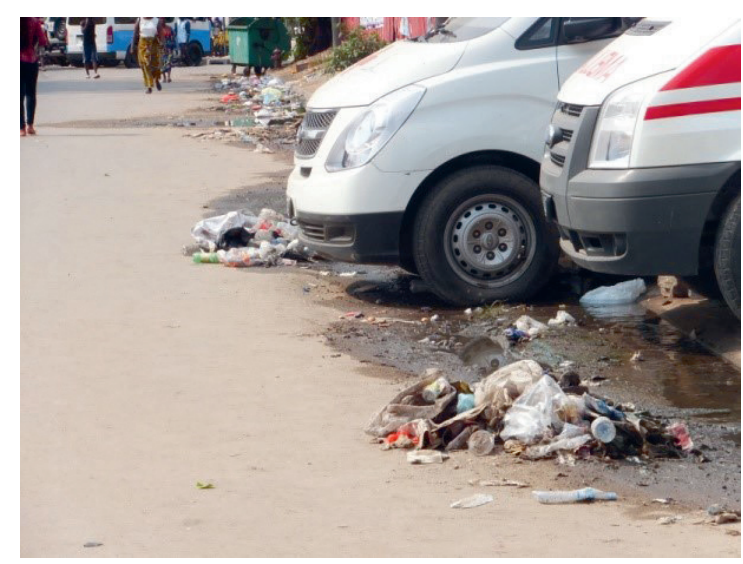

Figura 9.14 - Lixo nas ruas. Fonte: Nazareno Campos.

A própria imprensa local tem alertado sobre a situação em que se encontra o município (e que certamente se estende para toda a área metropolitana), através de reportagens específicas, a exemplo do Jornal de Angola, de 3 de junho de 2015, em reportagem intitulada "Concertação em Luanda - Apresentando Plano Municipal de Desenvolvimento", que, em sua chamada, assim se expressava:

A cidade de Luanda enfrenta vários desafios, desde melhoria do abastecimento de água, energia, saneamento básico, maior oferta e qualidade de serviços públicos de educação e saúde à construção de novos fogos habitacionais, viabilização dos programas de intervenção urbana, enquadramento do regime de propriedade urbana e uso do solo.

O Plano Municipal de Desenvolvimento (2015-2017) prevê uma série de ações por parte do poder público em seus diferentes níveis, sendo, contudo, difícil afirmar se, nestes tempos de crise econômica, conseguirá cumprir todas suas metas, visto que há críticas a respeito, como de representante da UNITA, Agostinho Camuango, segundo o qual "o Orçamento Geral do Estado 2015 para o municipio de Luanda é deficitário". De sua parte, a população tem preocupações mais concretas e imediatas, como o exposto por António Quintas, da comissão de moradores da comuna de Kinanga que "apresentou como principais preocupações a delinquência, saneamento básico, falta de luz, água e má conservação das vias", qual seja, aquilo que afeta o dia a dia das pessoas.

Tudo isso reflete o dinamismo atual da economia angolana, bastante ligado à produção de petróleo e de diamantes, com rápido crescimento, mas sem estrutura suficiente que dê conta deste. 


\section{Os efeitos da crise econômica e as dificuldades de Luanda e Angola na atualidade}

Apesar do pouco tempo que estive em Angola, pude perceber certo otimismo da população com o futuro do país, superando os entraves dos tempos de guerra e de uma sociedade dividida e arrasada pela guerra civil. Entretanto, em termos econômicos e sociais, o otimismo anda um pouco abalado à medida que os efeitos da crise econômica, que têm provocado dificuldades na economia mundial, têm seus reflexos sentidos também em Angola, haja vista que desde meados de 2014 tem havido um constante processo de desvalorização da moeda nacional, inflação e aumento do custo de vida, refletindo nos itens da vida diária, como alimentação, saúde e educação, ${ }^{14}$ criando descontentamentos dos mais variados - descontentamentos que têm levado a população à constante desconfiança quanto à lisura tanto do poder público como de setores privados em relação à suas ações, sendo constantes os comentários quanto a enriquecimentos ilícitos por parte de integrantes do poder público ou de membros de alto escalão de empresas privadas; além da preocupação de muitos quanto à crescente abertura da economia nacional aos capitais externos e o domínio que estes hoje representam.

Por outro lado, cabe ressaltar que as transformações sofridas por Luanda e Angola na atualidade afetam diferenciadamente sua população. A maioria convive com grandes dificuldades em seu dia a dia para viver em uma capital das mais caras do mundo, com um elevado custo de vida. Outra parte, contudo, embora numericamente reduzida, ostenta uma vida de grande consumo, viagens ao exterior, entre outras possibilidades. Essa situação não é estranha em países de rápido crescimento econômico, dominados por fortes elites econômicas e políticas, em grande medida favorecidas pelo poder público, ligadas à dinâmica capitalista mundial e disso se favorecendo. Nisso, se percebe que as contradições na sociedade angolana não parecem ser de fácil solução em curto espaço de tempo, mesmo que haja o esforço, por parte do Estado, de superar os problemas, proporcionando alguns resultados importantes, como a expansão do ensino superior, até então com pouca expressão e visibilidade, bem como o esforço de reconhecer as diferentes culturas e línguas, observado através do canal estatal, TPA, que apresenta programas, jornais e reportagens em línguas como umbundu e kimbundu. ${ }^{15}$ Todavia, a centralização política do MPLA enquanto partido do poder é sentida e constantemente comentada pela população, com críticas inclusive a ações que geram interesses individuais, o que, na afirmação de alguns, tem se espalhado pelos diferentes setores da sociedade.

14 Além disso, percebi, no período em que lá estive uma frenética procura por dólares, cujas filas nos bancos e casas de câmbio se avolumavam, sem que houvesse dólares suficientes à venda.

15 Embora línguas de menor expressão possam estar sofrendo processo de absorção e consequente desaparecimento. 


\section{Em viagem à província do Namibe}

A equipe de pesquisadores partiu em 3 de junho em direção ao sul de Angola, em veículo apropriado pertencente à Faculdade de Letras e dirigido pelo funcionário Manuel Domingos Diogo Neto, para os trabalhos que seriam realizados na região do deserto do Namibe.

Esse deslocamento por terra foi de grande valia em termos geográficos, pois facilitou uma melhor percepção da paisagem e de suas mudanças à medida que nos afastamos de Luanda em direção ao sul do país. De um espaço de forte concentração urbana da área metropolitana luandense, seguem espaços com pouca ocupação humana, a exemplo do vale do rio Cuanza e Parque Nacional do Quicama (Figuras 9.15 e 9.16), ou uma série de pequenas comunidades rurais, a exemplo de Quilunda (município de Sumbe, província de Cuanza Sul), com rica produção agrícola e venda em mercados locais e regionais, incluindo pequenas feiras à beira da própria rodovia nacional (Figuras 9.17 e 9.18).

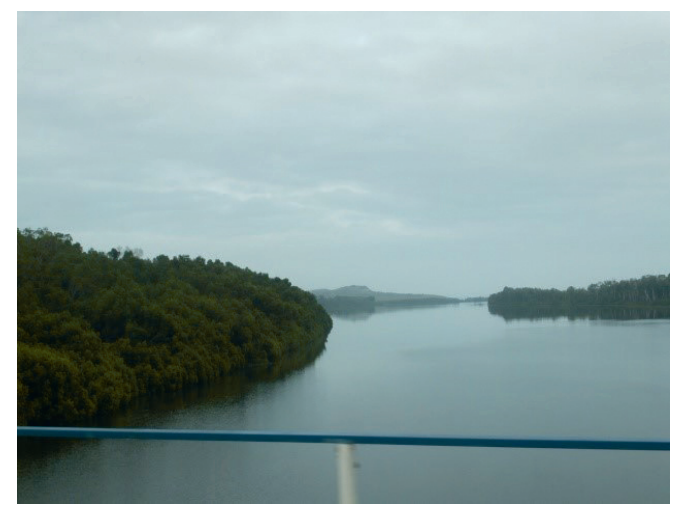

Figura 9.15 - Barra do rio Cuanza. Fonte: foto de Nazareno Campos.

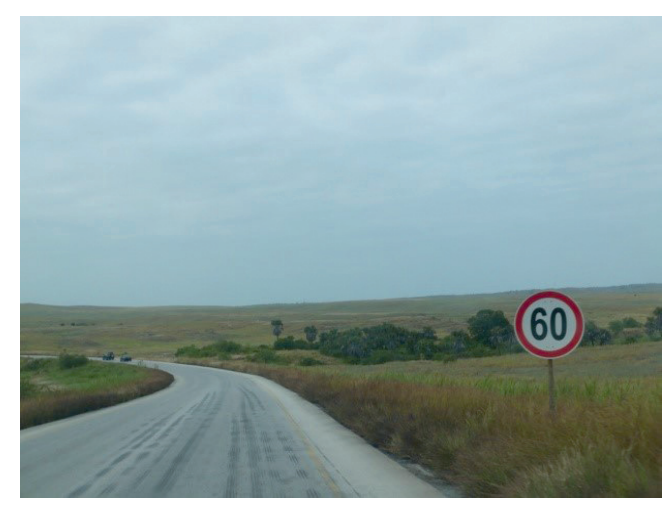

Figura 9.16 - Parque Nacional do Quicama, próximo ao Cabo Ledo (província de Bengo). Fonte: foto de Nazareno Campos. 


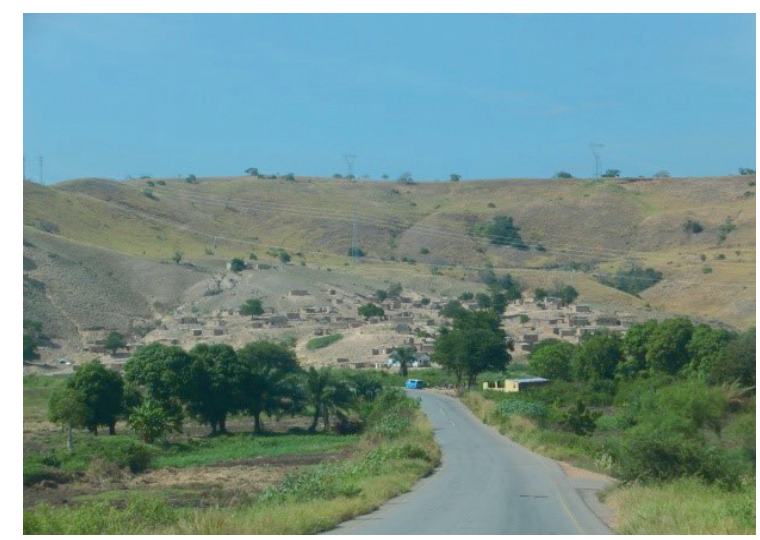

Figura 9.17 - Aspectos da vida rural na localidade de Quilunda, próxima ao rio Keve (província de Cuanza Sul). Fonte: foto de Nazareno Campos.

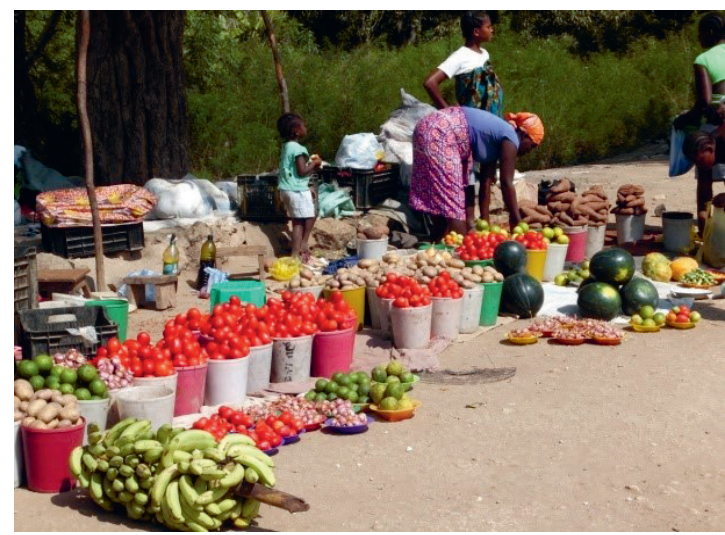

Figura 9.18 - Pequenas feiras à beira da rodovia nacional (província de Cuanza Sul). Fonte: foto de Nazareno Campos.

No trajeto, passamos por diversas cidades de porte pequeno e médio, além das capitais provinciais Huambo, Lubango e Namibe, onde visitamos órgãos públicos nos quais obtivemos material bibliográfico, cartográfico, além de diferentes dados e informações sobre a região desértica do sul do país.

Em Namibe, capital da província homônima, a equipe esteve reunida com o vice-governador provincial e administradores do município, no sentido de obter apoio da parte da administração pública, necessário à nossa estadia e atividades na região desértica, principalmente no sentido de logística de campo e infraestrutura. Nisso, o administrador municipal, senhor João Guerra, se mostrou bastante receptivo com as possibilidades do projeto Kadila para o interesse do Namibe e nos incentivou a não ficarmos restritos a visitar, como havíamos previsto inicialmente, apenas os povos da área do vale do Kuroka, em Njambasana, onde se localiza o CE.DO (Centro de Estudos do Deserto), mas a irmos também ao Par- 
que Nacional do Yona e lá visitar os vários povos pastores que vivem na região. Nesse sentido, enviou-nos à presença do vice-governador provincial para o setor econômico, senhor Alcides Gomes Cabral, com a intenção de que nos fosse providenciado um veículo mais apropriado, com motorista, para nos levar à região e lá visitar os povos pastores transumantes e conhecer um pouco de seus hábitos e costumes. Isso se confirmou, no período entre 7 e 13 de junho, que exporemos mais adiante, retornando após à cidade de Tombwa, que nos serviu de base para as atividades seguintes no CE.DO e em Njambasana.

Considerando o pouco conhecimento que tínhamos até então sobre a região desértica do sul do país e do modo de vida de suas inúmeras populações de pastores transumantes, foram necessárias algumas leituras prévias, que irei aqui descrever, sobre os aspectos ambientais e sociais da região do deserto do Namibe, antes mesmo de expor especificamente sobre as regiões visitadas: o parque do Yona e o vale do Kuroka, em Njambasana.

\section{Aspectos socioambientais do deserto do Namibe}

O Deserto do Namibe está localizado na província de mesmo nome, ao sudoeste de Angola, ocupando uma extensa superfície da província, ${ }^{16}$ incluindo espaços litorâneos. Conjuga paisagens planas dominantemente arenosas, platôs rochosos e montes isolados ou formando cadeias. À exceção do Cunene, a maioria dos cursos de água é intermitente, ficando sem água a maior parte do ano. Em termos de vegetação, destaca-se a presença do mutiati (Colophospermum mopane), cujas folhas são aproveitadas pelo gado. A composição florística torna-se menos variada à medida que se dirige para o litoral, cuja aridez mais extrema dá lugar a "campos de gramíneas de pouco desenvolvimento, onde aparecem "tufos" de acácias espinhosas que, através de suas vagens, acabam por ser um excelente contributo para a parca alimentação animal" (GOVERNO PROVINCIAL DO NAMIBE, 2014, p. 27). Também é presente a curiosa welwitschia (Figura 9.19), que só existe no deserto do Namibe e que representa a última possibilidade de alimento do gado nos períodos de extremas e longas secas. Igualmente, estão presentes diferentes espécies de cactáceas, a exemplo da cassoneira (Figura 9.20), cujo látex foi muito utilizado no passado. ${ }^{17}$

16 Com $56.389 \mathrm{~km}^{2}$ de área e população de 471.613 habitantes (INE, 2014, p. 111), a província do Namibe apresenta grande diversidade de povos e culturas, entre as quais estão presentes os povos pastores transumantes da área desértica. Geograficamente, a província se localiza a sudoeste do país, limitando-se ao norte com a província de Benguela, a leste com a província de Huila, a sudeste com a província de Cunene, ao sul com a República da Namíbia, de que é separada pelo rio Cunene, e a oeste está o Oceano Atlântico.

17 Assim o afirma Governo Provincial do Namibe (2014, p. 30) sem especificar em que sentido. 


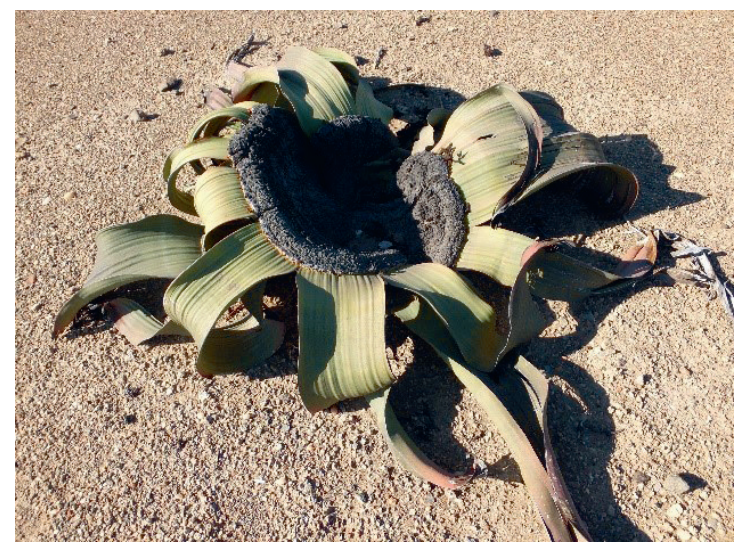

Figura 9.19 - A curiosa Welwitschia mirabilis, planta símbolo do Namibe. Fonte: foto de Nazareno Campos.

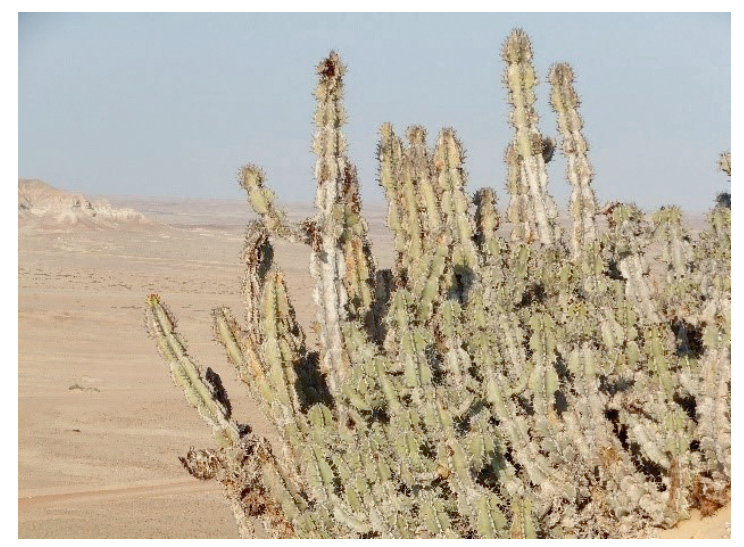

Figura 9.20 - A cassoneira, espécie característica de cacto. Fonte: foto de Nazareno Campos.

Considerado o mais antigo do mundo, o deserto do Namibe "desenvolve-se ao longo da costa atlântica, desde o sul da Namíbia até a costa sudoeste de Angola (Bentiaba), embora alguns geógrafos considerem que começa na África do Sul (Província do Cabo)" (GOVERNO PROVINCIAL DO NAMIBE, 2014, p. 18). No total, alonga-se por $1.600 \mathrm{~km}$ de norte a sul, com uma largura variando entre 50 e 80 quilômetros. ${ }^{18}$ Praticamente todo o litoral da província, de cerca de 480 $\mathrm{km}$, está inserido no deserto, sendo influenciado pela corrente oceânica fria de Benguela, cujo impacto no litoral angolano "manifesta-se pelas condições desér-

18 O nome namib tem origem em línguas locais e significa "lugar vasto, lugar sem gente, terras sem água, enorme lugar onde nada existe” (GOVERNO PROVINCIAL DO NAMIBE, 2014, p. 18). 
ticas na Costa do Namibe e semiáridas a sul de Benguela, e nevoeiros persistentes ao sul de Benguela e ao largo da costa meridional angolana" (GOVERNO PROVINCIAL DO NAMIBE, 2014, p. 33). ${ }^{19}$ Em decorrência da corrente de Benguela, o clima é árido em toda a fachada ocidental da província e possui, junto ao litoral, uma reduzidíssima precipitação, que por vários anos chega a ser inexistente, tanto na área de Namibe como no Tombwa, e mesmo na Baía dos Tigres. Mesmo assim, há presença de umidade no deserto, através das "neblinas e nevoeiros que provêm do mar e que durante a noite penetram dezenas de quilômetros para o interior", contribuindo assim para a sobrevivência da vida animal e vegetal (GOVERNO PROVINCIAL DO NAMIBE, 2014, p. 41-42).

Apesar de toda a dificuldade proporcionada pelo ambiente desértico, muitas vezes hostil, há um mosaico de populações que se espalham por toda a região do Namibe, a exemplo dos hereros, do tronco banto, que aí chegaram através de sucessivas migrações e que estão divididos em diferentes grupos, sendo os mais expressivos numericamente; populações mais antigas, de grupos minoritários, estão também presentes, caso dos kwisses e dos kwepes, cujas línguas estão, segundo o soba $^{20}$ Antônio Mbyapé, em amplo processo de desaparecimento e/ou absorção por grupos e línguas de maior expressão, caso dos mukubali. ${ }^{21}$ Não obstante, é bem difícil ter uma noção exata sobre quantos e quais realmente são os povos existentes no Namibe, haja vista que as bibliografias e classificações etnográficas a respeito foram, na maior parte, produzidas por viajantes e etnógrafos coloniais, "sob os paradigmas científicos de sua época, partindo de concepções etnocêntricas e critérios de identificação pautados em teorias e conceitos evolucionistas e racialistas" (ARGENTA, 2012, p. 18).A característica da pastorícia nômade ou seminômade na região desértica da província do Namibe vem de longa data, conforme menciona Torres (1950) ao retratar a expedição marítima de Pinheiro Furtado, que partiu de Luanda em maio de 1785, alcançando a Angra do Negro ${ }^{22}$

19 Afirma este órgão que "os fortes ventos carregados de areia, principalmente no período do 'Cacimbo', designam-se por 'garroa', a qual leva à necessidade de proteger as habitações, principalmente no Tombwa (cortina vegetal) e na Baía dos Tigres (construção sobre pilares)” (p. 33-34).

20 O soba é uma espécie de chefe, “é como são chamadas as 'autoridades tradicionais' que podem ser encontradas em todo o território angolano. Exercem funções de liderança nas comunidades rurais e atualmente trabalham vinculados às administrações municipais. Os 'cargos' se dividem em soba grande, soba, soba sekulo e soba adjunto” (ARGENTA, 2012, p. 5).

21 Conforme entrevista cedida em 19 de junho de 2015 na localidade de Njambasana, no vale do Kuroka.

22 Rebatizada pelo próprio tenente-coronel Luiz Cândido Cordeiro Pinheiro Furtado para Porto de Moçamedes, homenageando ao capitão geral de Angola, José Almeida Vasconcelos Soveral e Carvalho (Barão de Moçamedes). Após a independência, o porto, a cidade, a província e o deserto de Moçamedes recebem a designação de Namibe. 
em setembro daquele ano, afirmando que:

Os negros que Pinheiro Furtado encontrara na Baía não tinham povoação fixa; eram,
na maior parte, pastores vagabundos, sem nenhuma agricultura, que, possuindo
grandes rebanhos de excelentes carneiros, mudavam frequentemente de região, em
busca de pastagens, cuja existência Pinheiro Furtado notou por toda a praia (TOR-
RES, 1950, p. 40).

Portanto, o costume de criar gado (bovino, caprino) por parte de populações de pastores transumantes em diferentes espaços do deserto do Namibe é bem mais antigo do que se imagina. Inclusive, quanto à sua forma de alimentação, cuja carne do gado que criam não faz parte diretamente da dieta, mas principalmente o leite, conforme o autor anteriormente referido argumenta ao descrever a expedição terrestre de Gregório Mendes, segundo o qual, "os habitantes de Sinhebari não têm nenhum comércio. Vivem do leite dos seus gados, de alguns frutos silvestres e dos peixes que a necessidade os obriga a pescar" (TORRES, 1950, p. 47). ${ }^{23}$ Nessa mesma direção, Diniz (1998, p. 168) afirma que esses povos pastores do sul de Angola "têm no leite e produtos derivados a base de sua alimentação". Por sua vez, ao retratar o território Kuvale, Ruy Duarte de Carvalho vai mais além, afirmando que "o leite é a pedra ancilar de sua economia e da sua realidade global [e que] o consumo da carne é de alguma forma complementar ao do leite e sempre socialmente regulado, de tal maneira que acaba por inscrever-se numa política de utilização de excedentes" (2000, p. 129).Não obstante, a transumância tem amplo sentido, haja vista as agruras do próprio clima, sendo que, em grande medida, ela ocorre por uma ação, e, evidentemente, pela necessidade do próprio gado, pois, inclusive pelo que se percebeu em campo e nos relatos obtidos, é basicamente o gado que define o trajeto de migração à procura de água e pastagem.

Por sua vez, Diniz (1998, p. 168) assim o comenta:

[...] a distribuição esparsa e o escasso encabeçamento em bovinos, reflectem as condições limitantes do meio natural com decréscimos substanciais nos efectivos ao longo da época seca, devido ao gado ser forçado a afluir em massa aos escassos pontos de água, sobretudo às margens do rio Cunene, e aí, em virtude de sobrepastoreio excessivo, sucumbir por carência de pastos. Foi assim que, procurando contornar as dificuldades, alguns povos criadores adquirem hábitos de transumância, como é típico dos mucubais e de outras tribos da etnia herero, efectuando ao longo do ano

23 Essa segunda expedição, comandada pelo sargento-mor Gregório José Mendes, partiu de Benguela em setembro de 1785 e retornou a essa cidade em fins de dezembro. Quanto ao lugar, Sinhebari, dizia ficar à vista do mar, próximo aos $14^{\circ}$ de latitude. Nos mapas atuais, não percebi nenhum lugar com tal denominação - é possível, pela latitude, que se trate da região de Lucira. 
o circuito periódico de suas manadas pelos locais privilegiados da vasta região onde vivem, para em obediências aos costumes ancestrais, tirarem o melhor partido duma utilização eficiente da pastagem e da água.

Essa assertiva de Diniz sobre o povo mukubali (e considerando também outros povos do deserto) é aqui confirmada por Ruy Duarte de Carvalho, em sua obra Vou lá visitar pastores, acerca da plena relação pastor-gado (ou vice-versa) com a própria ecologia que acaba por determinar os deslocamentos, ao afirmar:

Ele está a ter em conta, para além da água, não só as quantidades de pastos e de recursos arbustivos acessíveis no lugar, mas também a relação entre as disponibilidades locais e a de outros lugares, porque a pastorícia ou a pecuária, aqui, hão-de depender, sempre, da diversidade entre as diferentes sub-regiões da zona e obrigar aos ajustamentos no tempo e no espaço que as transumâncias são. É a interpretação dos diferentes tipos ecológicos que determina a oportunidade das deslocações (CARVALHO, 2000, p. 121; grifos do autor).

É importante ressaltar que basicamente tudo o que foi aqui explanado foi percebido em ambas as áreas desérticas do sul angolano: a região do parque nacional do Yona e a região do vale do Kuroka, mais especificamente em Njambasana, conforme desenvolveremos nos itens a seguir.

\section{As experiências no Parque Nacional e comuna do Yona}

O Parque Nacional do Yona se constitui em um extenso espaço natural com uma área de $15.150 \mathrm{~km}^{2}$, cuja sede se encontra na localidade de Espinheira. Integra o Projeto Nacional da Biodiversidade, ligado ao Instituto Nacional de Biodiversidade e Áreas de Conservação (Inbac). Em termos internacionais, o Ministério do Ambiente da República de Angola assinou memorando de entendimento "para o estabelecimento de Área Transfronteiriça de Conservação Iona/Skeleton Coast entre Angola e Namíbia". ${ }^{24}$ Inserido no mesmo está a comuna ${ }^{25}$ do Yona (município de Tombwa), onde nos alojamos no período em que estivemos na região, em uma casa localizada em sua sede, cedida pela administradora local (Figuras 8.21 a 8.23).

24 Segundo o site do Ministério do Meio Ambiente de Angola: <www.biodiversidade-angola. com/area/parque-nacional-do-iona/>.

25 Administrativamente, a comuna é um equivalente do que no Brasil tratamos por distrito. 


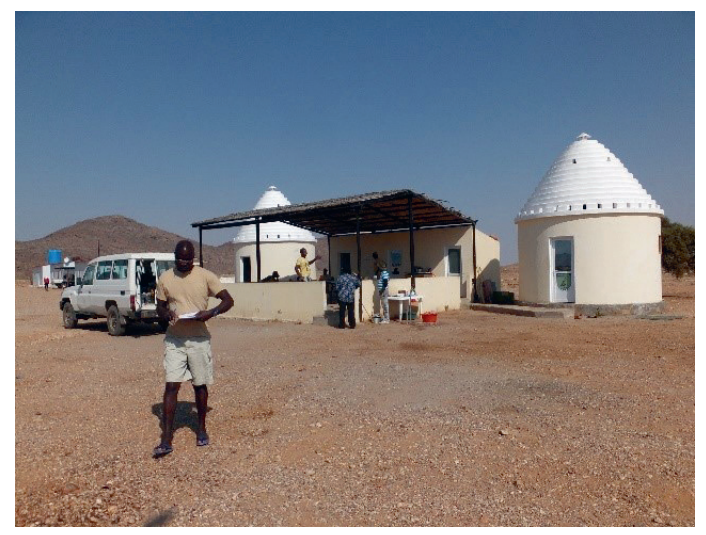

Figura 9.21 - Sede do Parque Nacional do Yona, em Espinheira. Fonte: foto de Nazareno Campos.

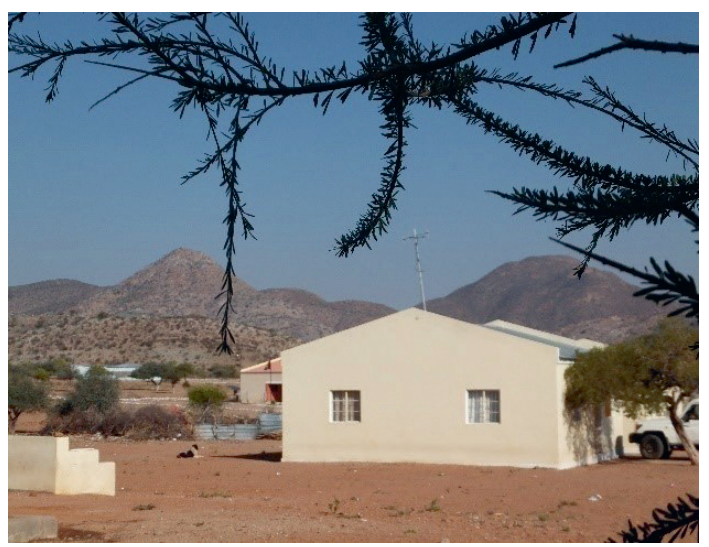

Figura 9.22 - Casa que serviu de alojamento na comuna de Yona. Fonte: foto de Nazareno Campos.

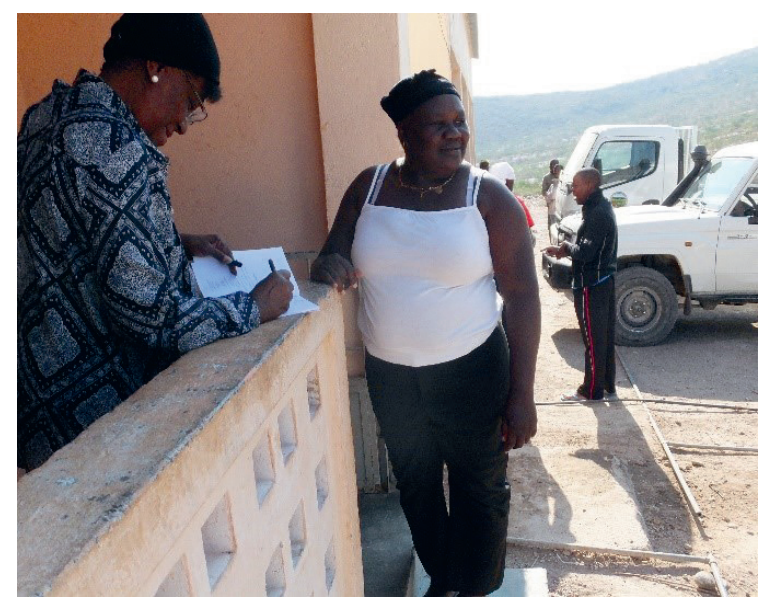

Figura 9.23 - Administradora da comuna recebendo livro da doutora Amélia Mingas. Fonte: foto de Nazareno Campos. 
Procedemos na área atividade empírica junto às comunidades tradicionais de povos transumantes criadores de gado (povos mukubale, herero, ganguela, muyihimba e outros), bem como atividades específicas na própria comuna do Yona, como veremos na sequência, considerando, entre elas, um inquérito linguístico com estudantes do oitavo ano da escola da comuna, realizado pelos professores Amélia Arlete Mingas e Narciso Benedito Homem. ${ }^{26}$ Em termos ambientais, a paisagem natural do parque do Yona é bastante complexa e heterogênea, pois, mesmo considerando a secura do lugar, com reduzida precipitação anual, ${ }^{27}$ as condições peculiares de cada sítio, em termos de umidade, formação edáfica, proximidade de rede hidrográfica (perene ou intermitente), maior superficialidade ou não de lençol freático, entre outras razões, veem-se presentes diferentes espécies vegetais. Percebe-se espaços sem nenhum tipo de vegetação; áreas acidentadas, com solo rochoso e presença de rios intermitentes, bem como espaços planos com solo arenoso e domínio de vegetação de gramíneas (Figuras 9.24 a 9.26).

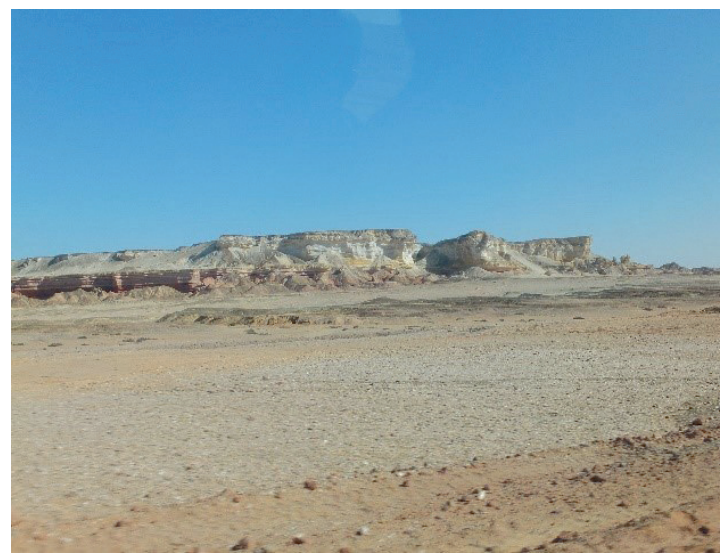

Figura 9.24 - Presença de solos totalmente secos. Fonte: foto de Nazareno Campos e Narciso Homem.

26 Trata-se de um grupo de dezesseis estudantes, de diferentes origens étnicas e linguísticas, conjugando seis línguas regionais: seis mukubale, dois herero, muyihimba e mandimba, um ganguela e umbumdu, além de dois que só falam português. Em termos etários, há uma grande diversidade também, estando o estudante mais novo (Kateto Chiangue - mukubale) com 12 anos, e o mais velho (Antonio Cinganfi - mandimba) com 49 anos. Os resultados do inquérito deverão ser posteriormente divulgados pelos professores que o realizaram.

27 Não considerando os longos períodos de seca, em termos normais, as precipitações giram em torno de $100 \mathrm{~mm}$ anuais mais próximos ao litoral e alcançando, na medida que avança na direção leste para o interior, até $500 \mathrm{~mm}$, onde as altitudes já estão em torno dos 800 metros. 


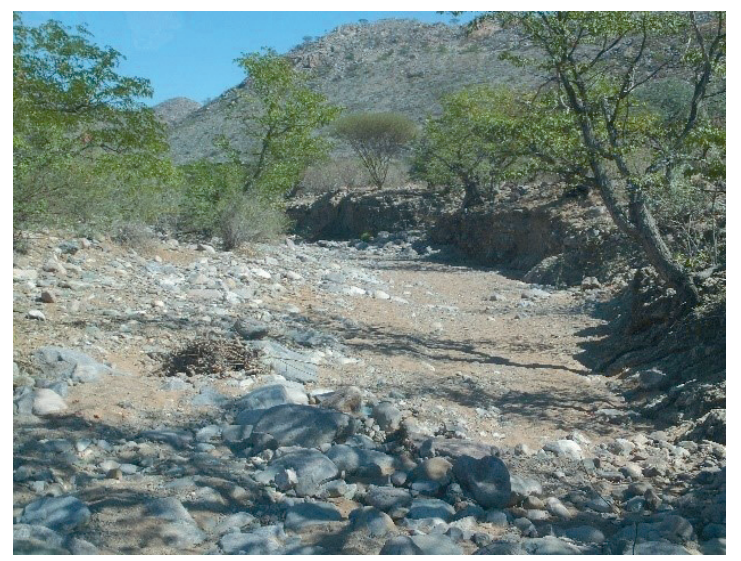

Figura 9.25 - Solos pedregosos em leito de rio intermitente. Fonte: foto de Nazareno Campos e Narciso Homem.

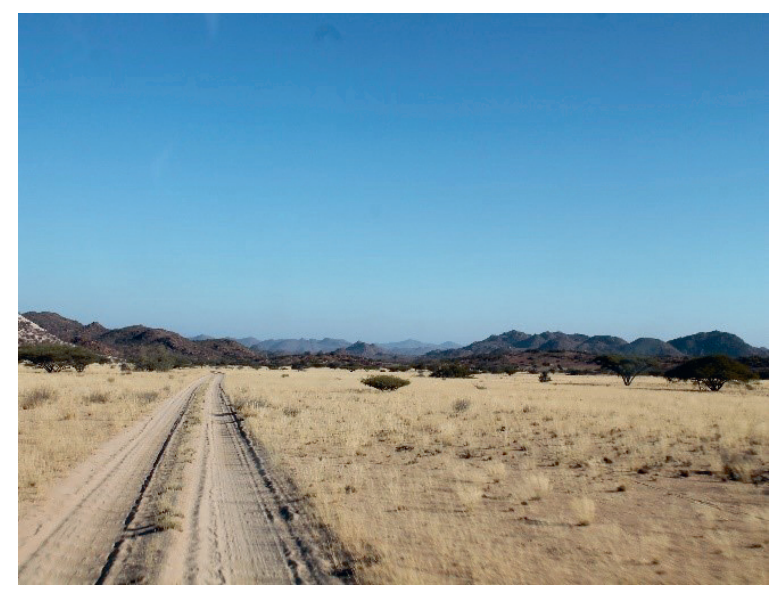

Figura 9.26 - Espaços planos e arenosos com domínio de vegetação de gramíneas. Fonte: foto de Nazareno Campos e Narciso Homem.

Portanto, surpreende a riqueza da vegetação, onde são vistas pequenas plantas, arbustos, alguns com flores, além de árvores de diferentes portes, que proporcionam excelente sombra para o gado e igualmente para as pessoas.

Constantemente, as folhas, frutos e sementes de diferentes plantas, arbustos ou de árvores (a exemplo das leguminosas como as acácias) servem de alimento para o gado ou para algum tipo de uso para as próprias populações. As casas, conhecidas por cubatas, são construídas com paus extraídos de pequenas árvores, fazendo uma armação em madeira, de forma arredondada, que, após, é coberta com uma mistura de argila e excremento de gado (Figuras 9.27 e 9.28). Retratando a realidade pesquisada no Kuroka e no Umbu, Argenta (2012, p. 105-106) detalha bem essas habitações: 
As cubatas são pequenas habitações cônicas, construídas com estacas de madeira fixadas ao chão numa base circular que mede cerca de dois metros de diâmetro e convergem para um vértice central medindo pouco mais de um metro e meio. Esta estrutura é coberta por uma massa feita com uma mistura de terra, estrume e um pouco de água. Os homens cortam os galhos de árvore, fabricam as estacas e fixam-nas no chão, e as mulheres são as responsáveis por recolher o estrume no curral, o que pode demorar alguns dias para conseguir quantidade suficiente para uma única cubata, fabricar a massa e cobrir a estrutura de madeira com ela. ${ }^{28}$

Aos homens é atribuída também a atividade da caça e o cuidado dos animais, acompanhando-os à transumância. Nos trajetos mais curtos, junto aos bairros e sambos, ${ }^{29}$ conforme observamos in loco, são geralmente crianças e/ou adolescentes que ficam responsáveis pelo deslocamento e cuidado com os animais (Figura 9.29).

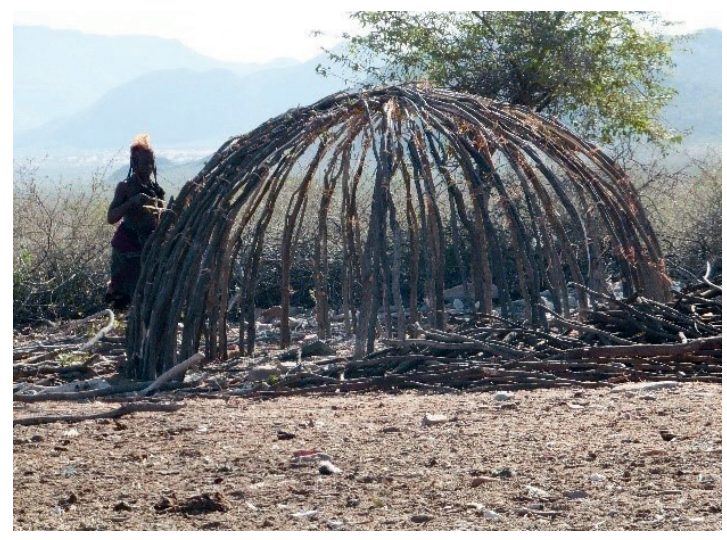

Figura 9.27 - Cubata em construção. Fonte: foto de Nazareno Campos.

28 Em comunidade que visitamos no Yona, era uma mulher, já com certa idade, que estava montando a estrutura da cubata, segundo afirmou, para um filho.

29 Os bairros são localidades com domínio de casas construídas em pau-a-pique por seus próprios moradores e sem as infraestruturas de uma comuna. E os sambos são "acampamentos temporários que mudam de localização em função do pasto e da água” (ARGENTA, 2012, p. 12), em que vive a família restrita, que pode mudar de lugar até três a quatro vezes durante o ano. 


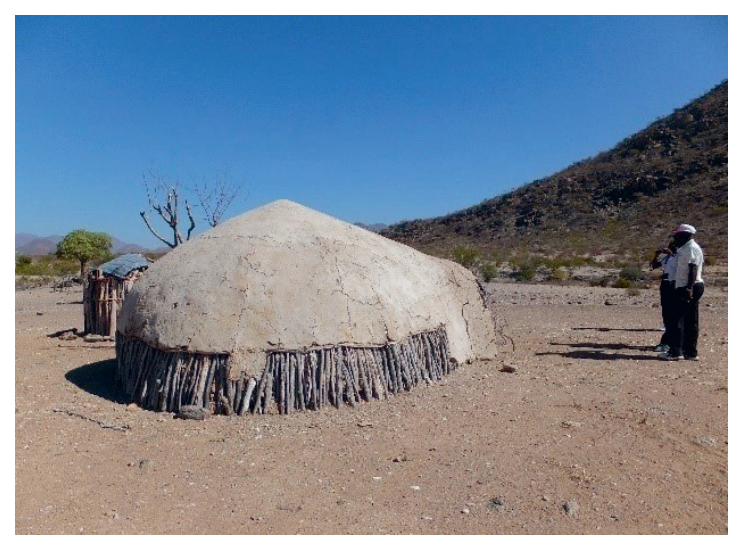

Figura 9.28 - Cubata construída. Fonte: foto de Nazareno Campos.

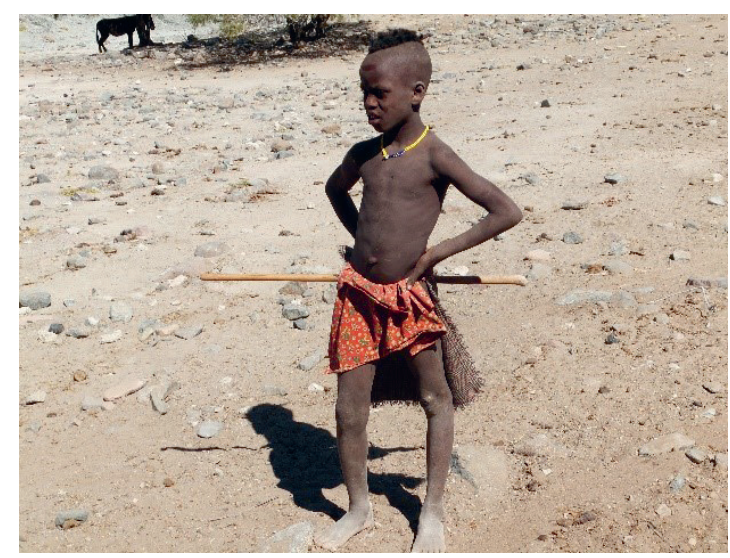

Figura 9.29 - Menino pastor observando o rebanho. Fonte: foto de Nazareno Campos.

O conhecimento da natureza lhes dá possibilidades de resolver situações que atualmente, para nós, exigem o uso tecnológico e o comércio. É o caso do fogo, por exemplo: com dois pequenos galhos verdes de plantas diferentes, um servindo de ponteiro e outro de base, friccionando-os, dá-se origem a uma fogueira com destreza e rapidez (Figuras 9.30 a 9.32), enquanto que, de um pequeno galho de umundema, fazendo com que sua ponta fique desfiada, faz-se uma escova de dente, possuindo papel curativo como no caso do flúor (Figuras 9.33 e 9.34). Nosso grupo teve a oportunidade de experimentar, e percebemos não só a eficiência, mas o cheiro e sabor que exala lembra em muito o flúor de nossas pastas de dentes. Tivemos ainda o relato de que as vagens secas e torradas de uma determinada planta (que não conseguimos saber o nome) servem para fazer uma bebida que equivaleria ao café (Figura 9.35); além de vários outros usos que não tivemos a oportunidade de observar. 


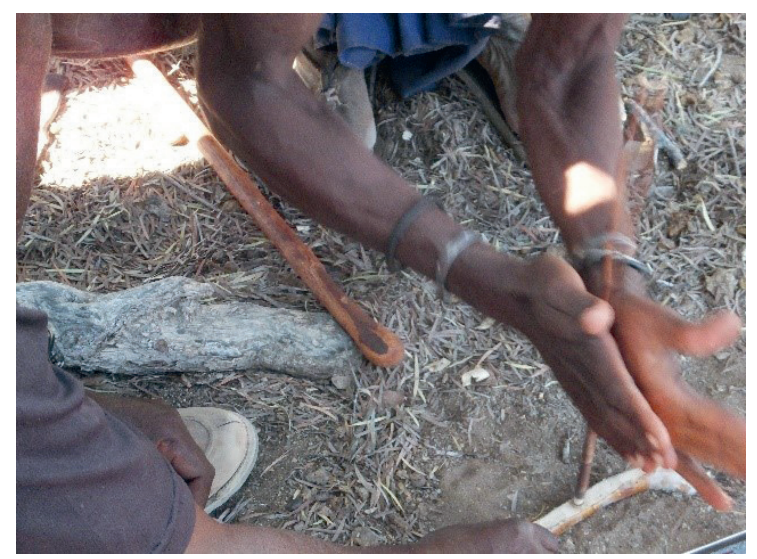

Figura 9.30 - Técnica tradicional de fazer fogo. Fonte: foto de Nazareno Campos.

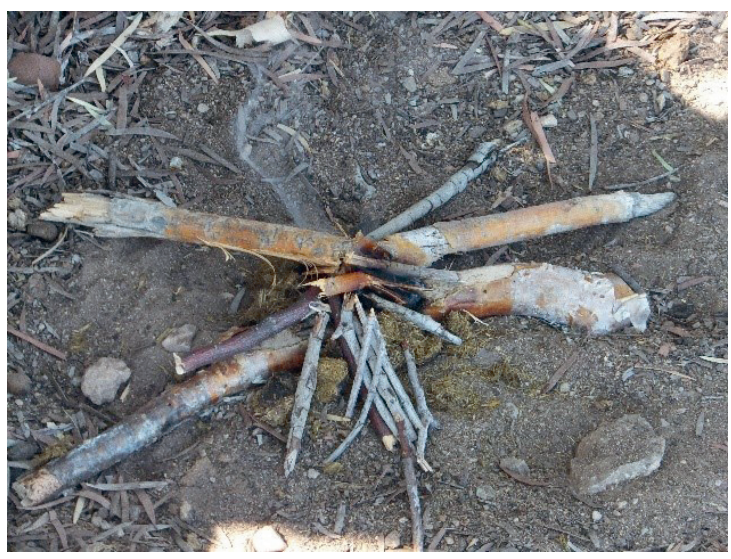

Figura 9.31 - Técnica tradicional de fazer fogo. Fonte: foto de Nazareno Campos.

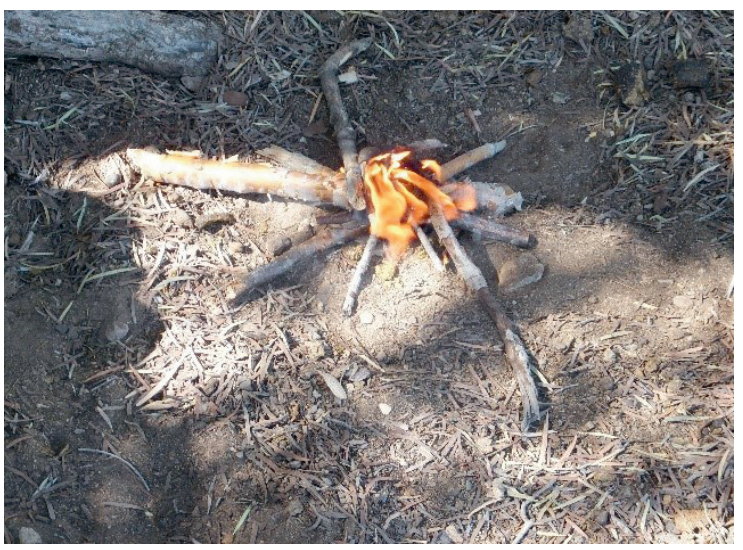

Figura 9.32 - Técnica tradicional de fazer fogo. Fonte: foto de Nazareno Campos. 


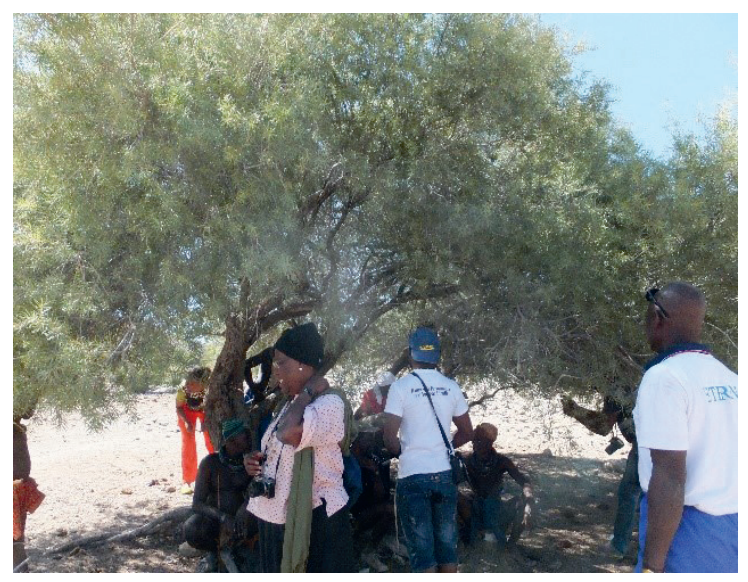

Figura 9.33 - Árvore umundema. Fonte: foto de Nazareno Campos.

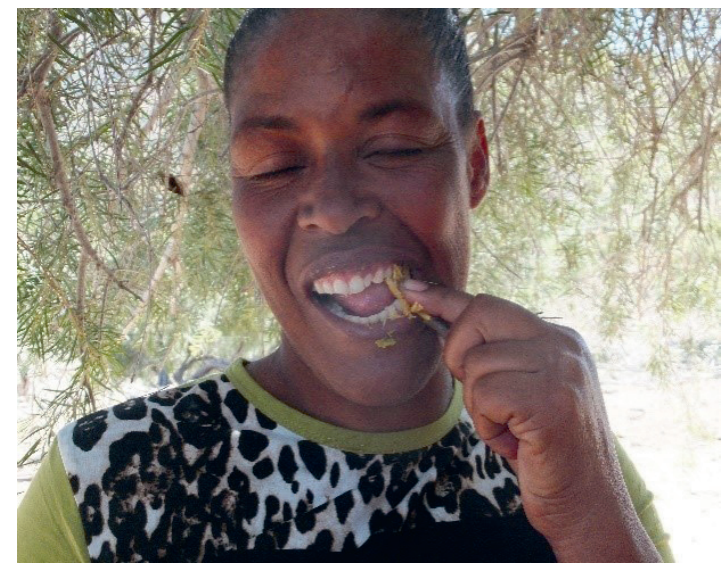

Figura 9.34 - 0 escovar os dentes com um pequeno galho de umundema. Fonte: foto de Nazareno Campos.

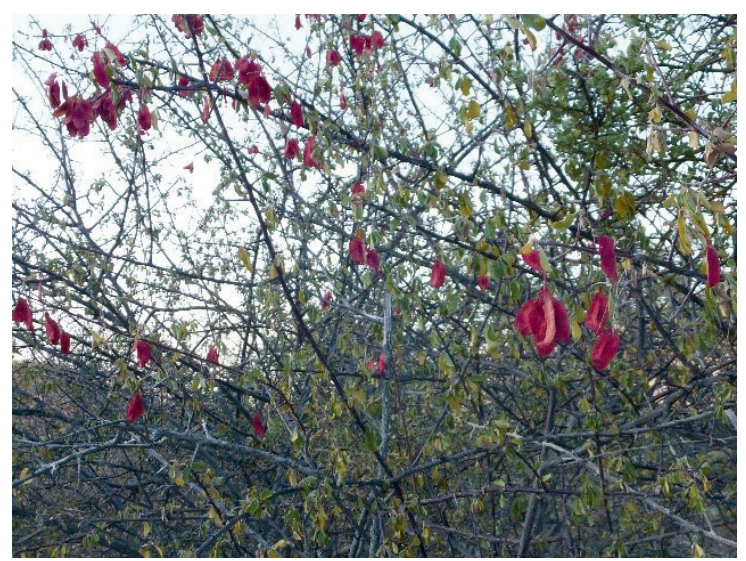

Figura 9.35 - Planta cujas sementes secas e torradas serve como bebida que faz a vez do café. Fonte: foto de Nazareno Campos. 
Portanto, há que se ressaltar a afirmação do antropólogo Samuel Aço de que a subsistência e os processos de sobrevivência das populações tradicionais do deserto do Namibe "só são possíveis graças aos conhecimentos profundos que estas comunidades possuem das potencialidades do ecossistema e da forma de como obter dele os recursos mínimos necessários à vida individual e social, em particular, os limites da sustentabilidade que suporta" (AÇO, 2014).

Além dessa relação sociedade-natureza, nos foi oportunizada a convivência, percepção ou explicação de alguns aspectos socioculturais dessas tradicionais populações transumantes do deserto do Namibe. Assim, tivemos a oportunidade de presenciar e tentar compreender as etapas de um ritual fúnebre. Soubemos disso já no primeiro dia que estávamos alojados na comuna de Yona, e cedo nos dirigimos para o local onde a atividade ocorria. Na verdade, o ritual já estava na fase final, isto é, no terceiro e último dia do processo. Antes mesmo de chegarmos ao local, o soba pequeno que nos acompanhou nos explicou que o ritual dura três dias, sendo que em cada um deles as atividades têm seu significado próprio, sendo respeitadas por todos. Por tal razão que, assim que chegamos, houve certo conflito entre o referido soba e uma mulher que ali se encontrava (que tinha domínio da língua portuguesa) e que, pelo que entendemos, não admitiu que chegássemos diretamente para conversar com o soba local, haja visto que, nesse dia, as atividades eram dirigidas e definidas pelas mulheres. Assim, foi ela quem serviu de intérprete junto ao soba, em relação a tudo aquilo que perguntávamos.

É tradição matar um boi nesse período, mas não qualquer boi. Os bois que pertencem a quem faleceu, ou a sua família (pelo que me ficou entendido) são postos a passar pelo local onde a pessoa que morreu foi enterrada; aquele que ao passar pela sepultura, parar e cheirar, é o que é abatido, pois significa que foi o espírito daquela pessoa que morreu que chamou por aquele animal. Depois de abatido o animal, pequenos nacos de carne são pendurados em arbustos (Figura 9.36), reservados a quem faleceu. No terceiro e último dia da cerimônia, a cabeça do boi é cortada e reservada junto com os chifres ao túmulo da pessoa falecida. No ato de matar o boi, uns estão a chorar, outros a cantar; já no dia do óbito, muitos cantam, porém, no dia de tirar luto, só o soba canta.

O processo de descarne do boi é feito ao ar livre, em cima de uma estrutura produzida de galhos e paus (Figura 9.37), sendo a carne cozida, sem sal, em grandes panelas, e depois cada presente se serve de pedaços e come, seguindo a ordem definida para aquele dia em um ritual prévio realizado pelo soba local ajudado por outro soba. Consiste na preparação, em uma bacia, de um composto de folhas em que é colocada água e são misturadas folhas ao líquido (Figura 9.38); concomitantemente, o soba local procede a uma reza na forma de canto. Após isso, cada um que vai comer a carne chega até o soba e, caso seu pai seja ainda vivo, aquele o unge na testa com as folhas - só após isso está liberado a comer. 
Caso a pessoa não tenha mais pai, então tem que colocar na boca um pouco do líquido da referida mistura, mas não engoli-lo, e sim cuspi-lo ao chão. Nosso grupo também passou por esse processo e comemos a carne ao final. Ao término, quando estão por ir embora, é oferecido um pedaço de carne (crua) para levar para casa, o que ocorreu também conosco.

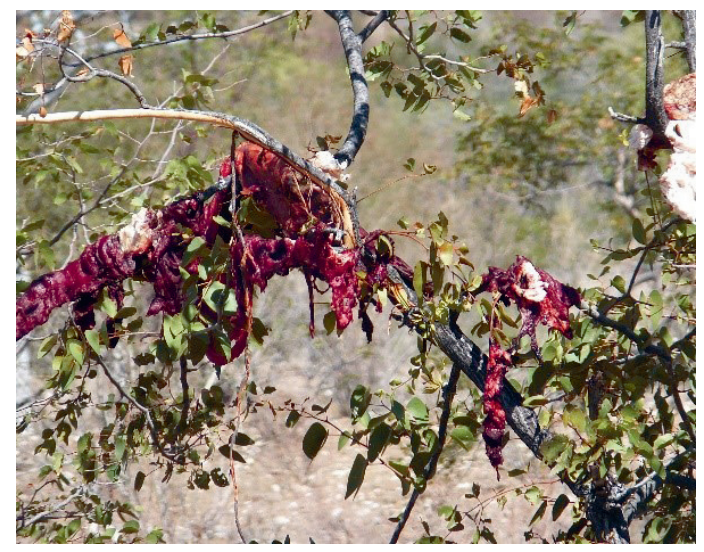

Figura 9.36 - Nacos de carne oferecidos ao espirito de quem faleceu. Fonte: foto de Nazareno Campos.

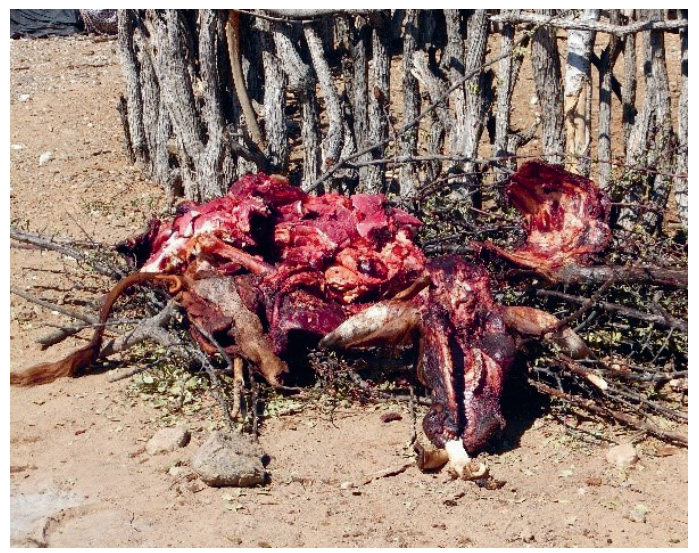

Figura 9.37 - Boi morto sobre galhadas. Fonte: foto de Nazareno Campos. 


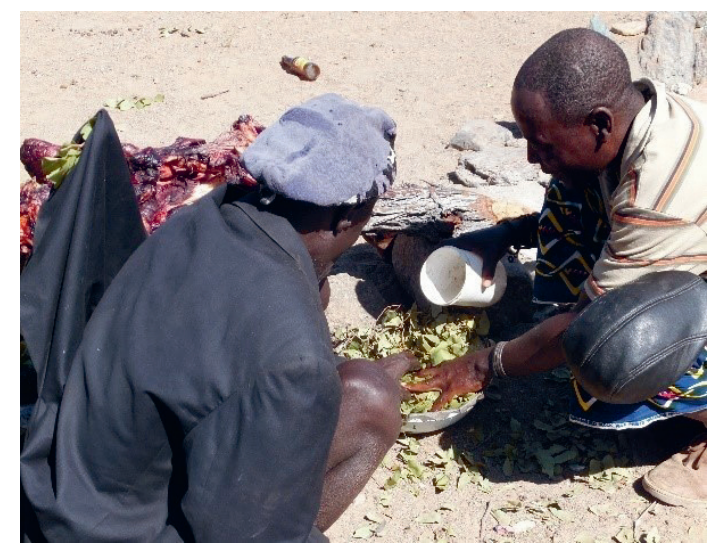

Figura 9.38 - Composto de folhas e líquido preparado pelo soba. Fonte: foto de Nazareno Campos.

Nesse mesmo dia, visitamos outras duas localidades. Numa delas, junto ao rio Kumbe, uma manada de cabritos aproveitava-se da água e da sombra de imensas árvores. O soba que nos acompanhava comentava sobre sítios em que, pela tradição, há "segredos" que operam no sentido de evitar a presença das crianças, haja vista a possível presença de animais ferozes ou, em épocas anteriores, a situação de guerra. O soba comentou também sobre o Morro do Soba, em que pessoas de fora, para atravessá-lo, só são permitidas se acompanhadas de alguém do grupo local. Comentou ainda que, como grande parte da área do parque está localizada próxima da fronteira com a Namíbia, as manadas em transumância pastam em território de lá, as de lá no lado de cá, qual seja, para as tradicionais populações de pastores transumantes o sentido de fronteira não é o administrativo que separa países. Embora no geral haja o entendimento dos diferentes grupos quando se cruzam em trajeto com o gado, por vezes ocorrem conflitos, considerando os escassos recursos, como água e pastagem; e também, quando ocorre, na oportunidade, roubo de gado, considerado um dos maiores delitos entre as populações pastoras do deserto, passível de punição. Segundo o soba Mbyapé, ele mesmo já teve que intermediar conflitos a respeito, um deles, por exemplo, citado por Milena Argenta (2012, p. 121) em sua obra:

No dia em que cheguei ao Umbú, Beiapé deslocou-se até a região do Kapolopopo, nos limites com a circunscrição do Virei, numa reunião com os sobas de lá na tentativa de apaziguar um conflito latente entre alguns mucubais que roubaram uma manada de mucurocas, e estes por sua vez armaram-se com seus porretes e Katanas para reaver o que lhes foi tirado a todo custo. 
Cabe salientar que, nessa e em outras situações de conflitos, a presença e intervenção do soba é fundamental, visto que ele é um membro da sociedade de grande respeito entre todos. Os sobas também intermediam "questões menos conflituosas, como o controle e monitoramento dos efetivos populacionais, mediam a comunicação e informação nas regiões das quais estão encarregados, estabelecem e regulam relações com as instituições externas e o Estado" (ARGENTA, 2012, p. 122).

Enfim, inúmeras outras situações continuam presentes entre as populações de pastores transumantes que circulam nesses espaços que englobam parte do território angolano e namibiano e conjugam o Parque Nacional do Yona e o parque do Skeleton Coast na área transfronteiriça. Mas nem tudo do que foi visto e observado é possível aqui desenvolver, pois carecemos das inter-relações necessárias para que se tenha um entendimento mais apropriado de totalidade.

\section{As experiências em Njambasana, no vale do Kuroka}

Depois de desenvolvidas as atividades em diferentes espaços do Parque do Yona, o o grupo retornou ao litoral, mais especificamente à cidade de Tombwa, tomada como local de apoio no período de realização das atividades na região do Kuroka e nas estruturas do CE.DO - Centro de Estudos do Deserto ${ }^{30}$ (Figura 8.39). Esse foi criado em 2007 e teve a coordenação do professor Samuel Rodrigues Aço até seu falecimento, em 2014. O centro realiza estudos nas áreas desérticas de Angola, visando ao conhecimento de suas características socioambientais, a proteção dos ecossistemas e o desenvolvimento adequado às culturas e sociedades locais. Considerando algumas dificuldades infraestruturais, os trabalhos em Njambasana tiveram um tempo mais reduzido em relação ao ocorrido no Yona, com atividades práticas de observação in loco.

30 Havia sido definido inicialmente que o grupo ficaria alojado no CE.DO, porém, preferiu-se o deslocamento diário (aproximadamente cnquenta quilômetros) entre o CE.DO e a cidade de Tombwa, cuja estadia nos foi proporcionada pela administradora adjunta do município, Benvinda Luzia da Graça Mateus, cedendo ao grupo o espaço físico e logística de deslocamento ao deserto, bem como contatos prévios com a comuna do Yona, cujas atividades acabaram ocorrendo antes. 


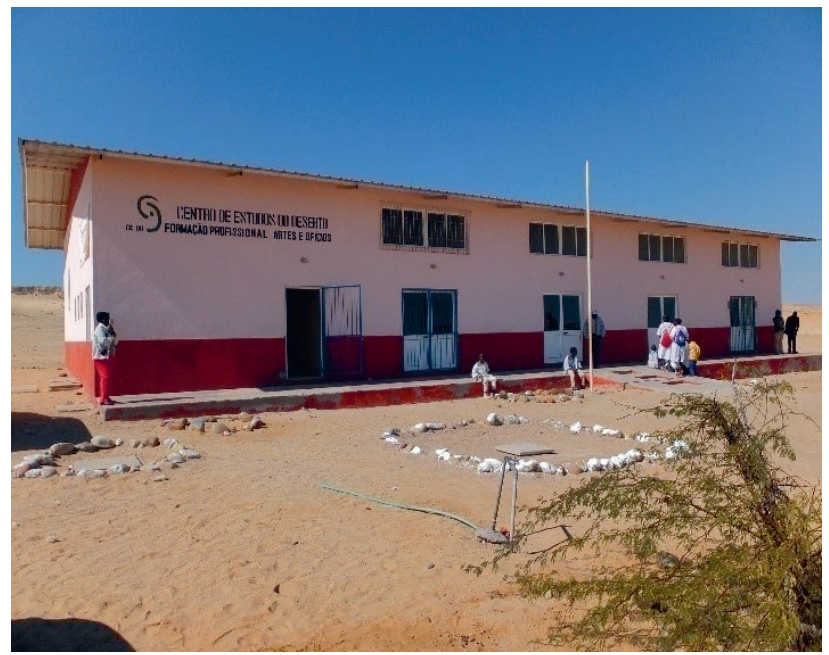

Figura 9.39 - Em Njambasana, o CE.DO e seu espaço de formação profissional, artes e ofícios. Fonte: foto de Nazareno Campos.

Pelo que nos foi relatado por membros da comunidade, em julho, toda a região está em pleno período de seca, razão pela qual encontramos pouco gado na área, que deveria possivelmente estar em processo de transumância, a procura de melhores fontes de água e pasto. O lago, que nos períodos de cheias do Kuroka aparece no espaço geográfico de Njambasana, existe ainda por um bom período após o rio já estar seco, mas não se fazia presente nesta época do ano (mês de junho) em que lá estivemos, permanecendo, contudo, alguma umidade, percebido no verde da paisagem. (Figura 8.40).

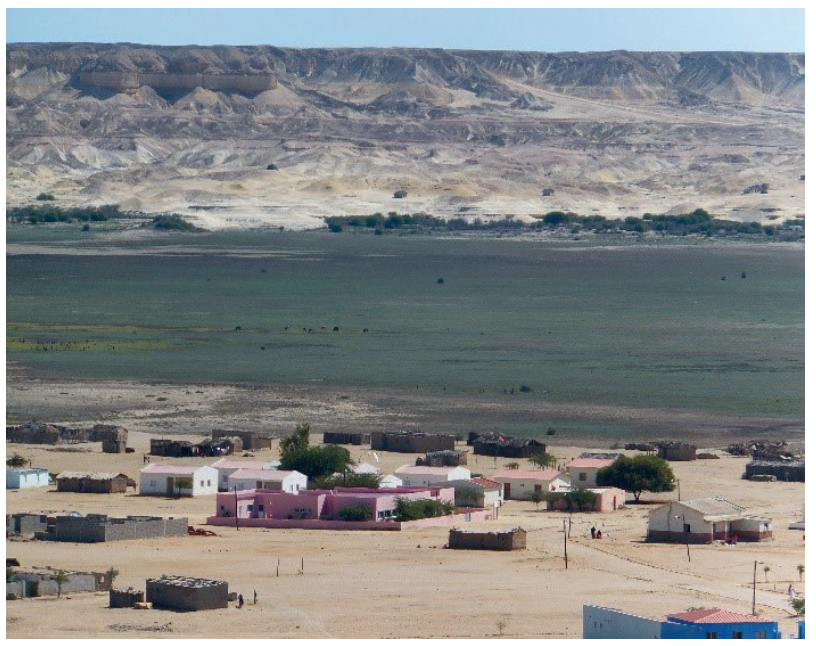

Figura 9.40 - Área do lago Njambasana durante o período de seca. Fonte: foto de Nazareno Campos. 
A presença de umidade fica ainda evidenciada em alguns elementos na paisagem, como focos de fumaça percebidos em Njambasana que, segundo relatos do soba Antônio Mbyapé, ${ }^{31}$ indica que grupos de agricultores estão queimando o mato seco e aproveitando o espaço que ainda resta para plantar - milho, feijão, batata doce, tomate, couve, repolho, cebola. Os considerados mais ricos possuem estrutura de ponteiros que perfuram o solo e extraem água, podendo assim plantar constantemente no mesmo lugar. Os agricultores conseguem as sementes no Tombwa, em cooperativas, como parte de programa institucional federal. Distante dali, bem próximo ao litoral junto à foz do rio Kuroka, em Tombwa, percebemos a presença de agricultores plantando no leito do rio, aproveitando-se da umidade que ainda permanece.O Njambasana se caracteriza, portanto, por um oásis às margens do Kuroka no meio de uma vasta região desértica. Isso fez com que algumas populações deixassem gradativamente de serem transumantes e se fixassem, embora boa parte delas tenha familiares com gado no mato, isso é, nas áreas de pastagens naturais afastadas do lugar.

Argumenta ainda o referido soba que, nos últimos quatro anos, choveu o suficiente para os animais. Mesmo assim, é realizada a caminhada diária numa média de três a quatro quilômetros até encontrarem água nas cacimbas, conforme detalhada descrição de Milena Argenta (2012, p. 224):

As cacimbas são poços artesanais cavados no leito seco de um rio, cuja proximidade é determinante nos percursos de transumância dos diferentes grupos de pastores. É um lugar de encontro de diferentes famílias, gerações, mulheres e homens em visitas matinais que se prolongam ao longo da tarde com o beber dos rebanhos e o secar dos panos, as brincadeiras juvenis e o banho fresco com a água salobra que brota da terra. Nas zonas afastadas onde se encontram as pastagens naturais, as cacimbas são a única fonte de água durante quase um ano inteiro de seca, onde os pequenos levam os cabritos para beber e os grandes levam os bois, as mulheres levam baldes e bacias para lavar os panos, e galões de vinte litros, que serão preenchidos e carregados nas costas de uma mula no caminho de volta para casa.

Os vários caminhos de trajeto do gado são conhecidos desde tempos imemoriais. Os bois conhecem bem os locais onde há água, árvores de boa sombra onde possam deitar, e onde há capim; portanto, é o gado que acaba definindo o caminho. No geral, nos trajetos mais curtos, o gado que não possui vitelos fica solto no espaço em que se encontra, mas os que possuem vitelos retornam para o ponto de partida, até que aqueles deixem de mamar, o que define o movimento ser diário. Portanto, o trajeto à procura de capim e água no Kuroka não é de tempo longo,

31 Um dos poucos remanescentes do povo e língua kwepe e que atualmente está basicamente absorvido pelo povo e lingua mukubale. 
diferente do que ocorre no Yona. Mas já houve períodos de extrema seca em que muito gado morreu por falta de água e até de alimento, e, nesse caso, acabam também ocorrendo os movimentos longos, caracterizando a transumância, onde gado do Umbú, por exemplo, lugar de origem e onde vivia o soba Mbyapé, tem que ir até o Yona, um trajeto que, conforme especificado pelo soba, pode superar os cem quilômetros.

Atualmente, o soba Mbyapé vive no bairro chamado Túe, distante cerca de três quilômetros do CE.DO (Figura 9.41), desde que assumiu o cargo de primeiro secretário do MPLA no Kuroka. Ele afirma possuir, nos períodos de chuva, entre quinhentas a mil cabeças de gado, argumentando que aqueles considerados mais ricos chegam a ter três mil, e há casos inclusive de pessoas que têm até doze mil cabeças. Diz ainda que nem todos possuem bovinos, e nesse caso pode haver, da parte de quem tem gado, o "empréstimo" de bois, isso é, ceder alguns garrotes já desmamados para que essa outra pessoa os crie para si, sendo que é o proprietário dos bois quem controla o processo. ${ }^{32}$

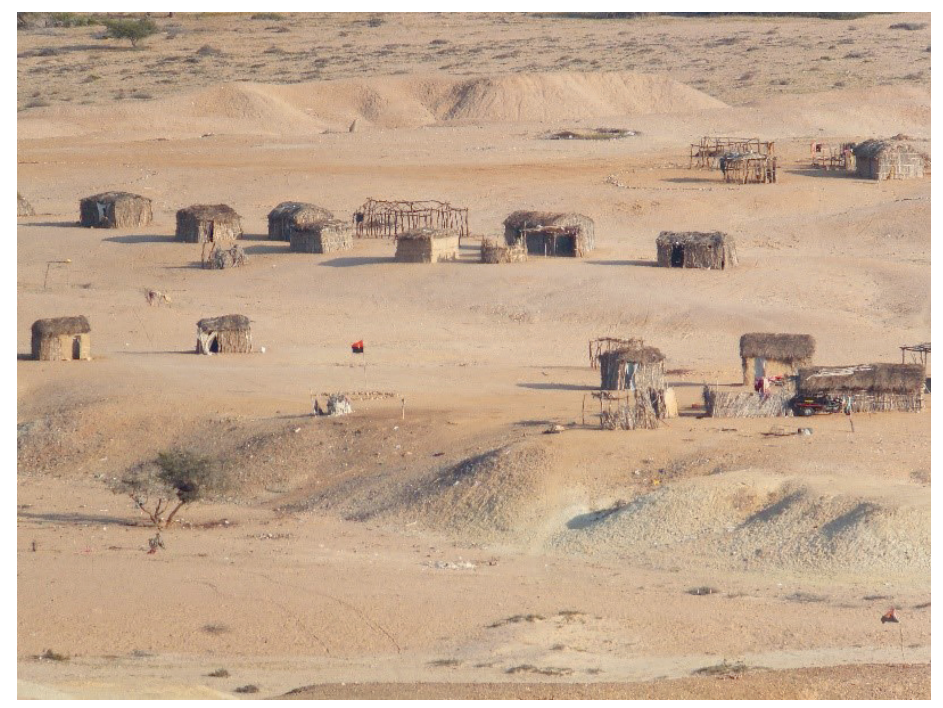

Figura 9.41 - Uma vista parcial do bairro Túe, onde vive o soba Mbyapé. Fonte: foto de Nazareno Campos.

Entre muitas das populações pastoras do deserto, não há venda do gado, sendo o leite e subprodutos (como uma espécie de iogurte) a base da alimentação, haja visto que o gado é criado com a intenção de possuirem quanto mais puderem (sinal de riqueza) e não de consumirem. Assim sendo, a carne só é consumida

32 Se por acaso aquele que recebeu "de empréstimo" o gado vier a falecer, e a questão da confiança em relação ao que cedeu estiver abalada ou não mais existir, pode ocorrer deste último pegar de volta o gado que havia cedido. 
em ocasiões especiais. O soba Mbyapé cita algumas delas: em um funeral (como aquele que presenciamos no Yona); na comemoração dos 15 anos de uma filha, cuja atribuição em realizar a festa é do pai; em festa de casamento, que tem se tornado algo comum na atualidade; nas cerimônias oferecidas em determinadas ocasiões, como em doenças na família; e em homenagem aos espíritos ancestrais, conhecido por Kulikutila, em que são mortos de três a quatro bois e participam familiares que por vezes viajam longas distâncias para vir à festa. Embora o soba não nos tenha evidenciado diretamente, Argenta (2012) afirma em sua pesquisa que o consumo de carne também está presente em situações de nascimentos e no período da circuncisão dos meninos; e Carvalho (2000, p. 173), ao comentar sobre os Kuvale em Vitetehombo, afirma que: "podem certas famílias abater um cabrito de vez em quando. Mas apenas quando há de fato muita fome, e é só para alguns, para os mais necessitados".

Mas há também grupos que comercializam, embora nem sempre todo o gado ou aquele considerado melhor, preferindo, por exemplo, comerciar um touro já mais velho ou uma vaca que já não dá mais cria. Há, inclusive, comerciantes que saem de Namibe e levam à área desértica produtos como arroz, farinha, fubá, trocando por gado, principalmente em período de seca. Ainda quanto ao comércio, há toda uma relação que é baseada em um direito costumeiro, com uma forte oralidade. Segundo afirma Caley (2005, p. 200), o costume, de tanto ser repetido, "[...] acabou por traduzir a ideia de norma, não escrita, evidentemente, e passou a ser conhecida e experimentada pelos povos que a praticam através dos tempos". O que certamente acontece também em relação a Angola como um todo e região do Kuroka e Yona em particular.

Algo que percebemos, não só no Kuroka, mas também no Yona, foi a pouca presença de cavalos e, embora se perceba em maior quantidade, de burros, possivelmente pelo fato de serem considerados animais de mais difícil acesso, só possível àqueles considerados mais ricos. Não obstante, cabe ressaltar que, para o nosso padrão ocidental de diferenciação social, pouco se consegue distinguir quem é mais ou menos rico. Se necessitaria de um tempo substancialmente maior para se compreender com mais precisão o que representa para essas populações de pastores transumantes a diferenciação social inter e intragrupo. Certamente, o número de gado que cada família possui é um diferencial importante; terra não parece ser um problema, visto que ela tem um forte sentido de uso comum, e não de propriedade. Mesmo o domínio das fontes de água e de pastagens recai numa tradição de uso comum.

Salienta-se que, fora do espaço específico dos bairros e sambos, ou de outros espaços característicos de vivência das tradicionais populações dos povos pastores transumantes, como junto às cacimbas ou no mato, observou-se que, tanto na localidade de Njambasana como na comuna de Yona, há todo um aspecto de 
urbanidade, com a presença do poder público (provincial, nacional), por meio do setor administrativo, da escola, centro de saúde, água encanada, luz elétrica e as novas casas de alvenaria, padronizadas, construídas pelo governo, contrastando com as tradicionais moradias em madeira e palha (Figura 8.42).

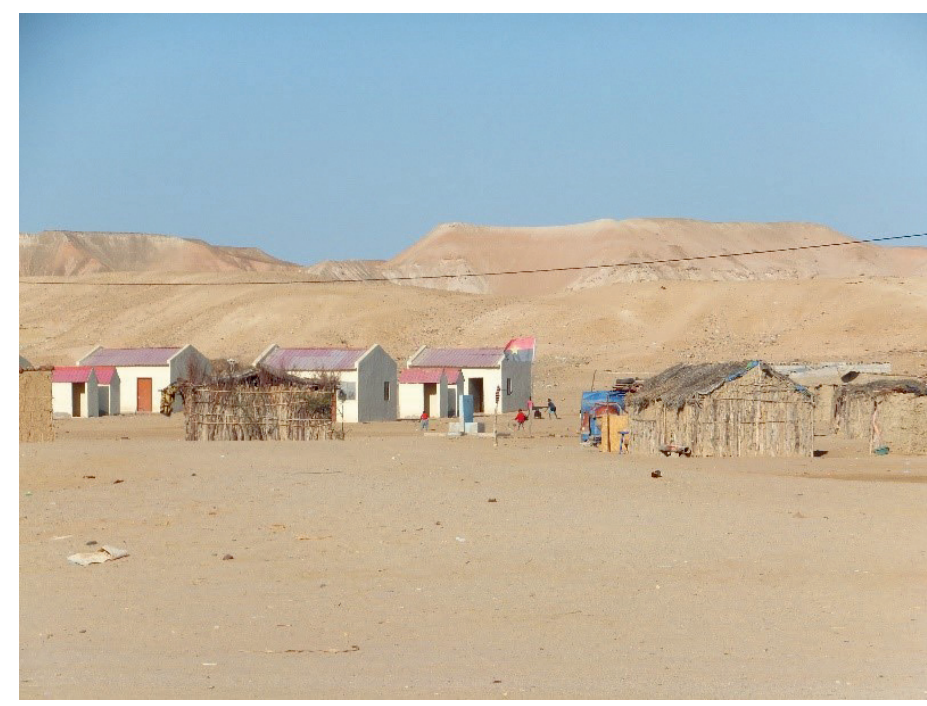

Figura $9.42-0$ aspecto diferenciado entre as novas e as tradicionais casas. Fonte: foto de Nazareno Campos.

A luz elétrica é proporcionada por um pequeno gerador local, e só é possível entre as $18 \mathrm{~h}$ e $22 \mathrm{~h}$. Quanto às novas casas padronizadas, tivemos informação de que há famílias que as recebem, ocupam por um tempo e depois acabam voltando para sua tradicional casa. Segundo consta, em um clima desértico, de grande amplitude térmica diária, as casas de alvenaria acabam por ser muito quentes durante o dia e frias à noite, razão que pode explicar seu abandono; além do que, considerando as próprias diferenças em relação à nossa cultura ocidental, a noção de praticidade e conforto é certamente diferente.

\section{Considerações finais}

Concluídos os trabalhos na região desértica do sudoeste angolano, retornou-se à Luanda para possíveis complementações e término das atividades. Nisso, foram realizadas ainda algumas reuniões de trabalho, destacando-se o encontro com pesquisadores da área de geografia e biologia do Instituto Superior de Ciências da Educação (ISCED) em Lubango, ${ }^{33}$ capital da província de Huíla, os quais

33 Mais especificamente com a professoras Fernanda Lage (área de biologia) e Valter Chissingui (geografia). 
chamaram a atenção para a participação do Ministério do Ambiente em projeto sobre transumância no sul de Angola desde 2013, incluindo as províncias do Namibe, Huíla e Cunene. Estivemos, também, na Faculdade de Ciências Sociais da UAN em Luanda, com a vice-decana, professora Luzia Conceição Pitra Milagre, e com o professor Luiekakio Afonso (da área de geodemografia), tencionando o estreitamento de laços entre esta Faculdade e o projeto Kadila.Em termos gerais, a experiência vivenciada em Angola em junho de 2015 foi muito importante e bastante proveitosa, contribuindo no desenvolvimento das atividades inerentes ao projeto Kadila.

Havia de minha parte grande desconhecimento quanto à realidade das regiões desérticas do sul angolano e de suas populações de pastores transumantes, o que não era muito diferente em relação aos pesquisadores angolanos, acostumados ao meio urbano de uma metrópole como Luanda. Assim, a vivência que tivemos no deserto do Namibe, mesmo que por um curto espaço de tempo, foi fundamental para o acúmulo de conhecimentos sobre a região, como os diferenciados aspectos de sua sociedade, economia, cultura e meio ambiente. Nisso, pudemos observar que, nos espaços geográficos em que a pesquisa ocorreu empiricamente - vale do Kuroka em Njambasana e Parque Nacional do Yona - há uma grande riqueza e heterogeneidade de paisagens, povos e culturas, presentes em diferentes aspectos de sua vida diária. Observaram-se as especificidades em cada tipo de povo cuja transumância é parte inerente de sua vida, quanto à ocorrência ou não de comércio de gado; as suas inter-relações e/ou influências com o meio exterior; e, inclusive, as transformações sofridas no transcorrer do tempo, ao se comparar os elementos constituintes do passado em relação ao presente.

Todavia, a heterogeneidade, bastante interligada a relações sociais e de produção pré-capitalistas, não é constante, nem no tempo nem no espaço. Ela sofre uma incessante pressão de elementos que fomentam a homogeneização, que já são percebidos nos relatos, documentos e referências coloniais, com grande carga de preconceitos e uma imagem de África que não é a mesma que vê o próprio povo africano. Os preconceitos não só permanecem, como até se ampliam, dependendo dos diferentes contextos socioculturais e econômicos. Eles estão hoje dominados pelo discurso da modernidade, que evidencia um olhar depreciativo em relação a diferentes populações, como é o caso dos povos pastores do deserto. ${ }^{34}$ No site

34 Milena Argenta (2012, p. 64) chama a atenção para o filme-documentário "Pastores do Deserto", do diretor Tando Minguiedy, exibido em 2011 no IV Festival Internacional de Cinema de Luanda, em que aparece um determinado empresário defendendo que o sistema produtivo daquelas populações é irracional, por não gerar, no seu entender, riqueza para a província. Nesse mesmo documentário, a administradora do município do Virei conclama empresários a aplicarem na região, na criação de gado. 
(www.rtp.pt/programa/tv/p26733) é exposta a seguinte afirmação: “Atualmente, esta sociedade sofre as ameaças da globalização, mas apesar dos inúmeros projetos que muitos consultores e investidores projetam para o Namibe, não será fácil alterar os hábitos destes nómadas" - qual seja: a tradicional alusão de que povos desse tipo são contrários ao progresso.

É preciso não esquecer que nisto tudo há também a presença do Estado. Este fomenta a modernização através de vias institucionais, a exemplo dos programas de extensão rural, o que não é privilegio de Angola, mas tem sido a tônica na maioria dos países na atualidade, seguindo a dinâmica dos interesses do capital.

Nessas visões, a realidade é analisada não em sua totalidade e em toda sua diversidade, mas numa lógica dicotômica em que se contrapõe o "civilizado" e o "atrasado", incorporando, no entender de Argenta (2012, p. 70), "noções presentes no projeto de desenvolvimento e modernização difundido aos quatro cantos do país, que em algumas ocasiões contrapõe o étnico ao moderno, e proclama a unificação de todos os povos sob o manto da nação angolana”, em detrimento das especificidades regionais e locais. O que muitas vezes é corroborado pela institucionalização da autoridade tradicional dos sobas e usa inserção aos ditames do MPLA.

Enfim, este "descompasso entre uma visão desenvolvimentista redentora e acelerada e as experiências marcadas pelas práticas locais" (BITTENCOURT, 2010 , p. 139), situação constante no período colonial, pouco parece ter mudado com a independência. As classes dominantes, considerando seus interesses, fazem permanecer e até ampliar esse descompasso, em que inúmeras populações tornam-se cada vez mais desconsideradas, invisibilisadas, caracterizadas como sinônimo de atraso, mesmo que determinados programas governamentais tentem fortalecê-las.

\section{Referências}

AÇO, S. R. O centro de estudos do deserto. Njambasana: Kadila - Observatório da Transumância, 2014. Disponível em: <http://kadila.com.br/o-centro-de-estudos-do-deserto/>. Acesso em: 16 jun. 2016.

ARGENTA, M. Marcas da etnicidade: indumentária e pertença no Curoca, sudoeste de Angola. 2012. Dissertação de Mestrado - CFH/UFSC, Florianópolis, 2012. 173 p.

BITTENCOURT, M. Angola: tradição, modernidade e cultura política. In: REIS, Daniel Aarão et al. (Org.). Tradições e modernidades. Rio de Janeiro: Editora FGV, 2010.

CALEY, C. Contribuição para o pensamento histórico e sociológico angolano. Luanda: Editorial Nzila, 2005. (Coleção Ensaio, v. 39).

CARVALHO, R. D. de. Vou lá visitar pastores. Rio de Janeiro: Griphus, 2000. 
DINIZ, A. C. Angola e o meio físico e potencialidades agrárias. Lisboa: ICP - Instituto da Cooperação Portuguesa, 1998.

GEO - África. 2. ed. São Paulo: Abril Cultural, 1977. v. 5.

Governo Provincial do Namibe (Coordenação de Miguel A. C. e Maria E. V. O.). Namibe: Terra da felicidade. Luanda: Chá de Caxinde Editora, 2014.

INE - Instituto Nacional de Estatística. Resultados preliminares do recenseamento geral da população e da habitação de Angola - Censo 2014. Luanda, 2014.

Concertação em Luanda: Apresentando plano municipal de desenvolvimento.

Consertação em Luanda: Apresentando plano municipal de desenvolvimento. Jornal de Angola, Luanda, 2015. p. 5.

SIMÕES, N. Algumas notas sobre a economia de Angola. Boletim da Agencia Geral das Colônias, Lisboa, ano 5, n. 47, p. 3-36, 1929.

TORRES, M. J. de M. O distrito de Moçâmedes nas fases da origem e da primeira organização (1485-1859). Lisboa: Divisão de Publicações e Biblioteca: Agência Geral das Colônias, 1950. 